\title{
Apartamentos duplex: uma ideia moderna sobre o morar e a proposta de uma tipologia habitacional
}

Duplex apartments: a modern idea about housing and the proposal of a housing typology

\author{
SABRINA STUDART FONTENELE COSTA ${ }^{\prime}$ \\ Universidade Estadual de Campinas / Campinas, SP, Brasil
}

RESUMO: Este artigo se propõe a compreender como se deu a ideia da vida moderna entre os empreendimentos vinculados ao movimento moderno, utilizando como objeto de análise os apartamentos duplex. Os arranjos espaciais vinculados a esta tipologia se relacionavam originalmente com a ideia de economia na construção e com o discurso da funcionalidade do espaço, que sugeria novas práticas domésticas ao considerar a entrada da mulher no mercado de trabalho, como também sua menor participação na organização do lar e da família. Para tanto, foram analisados exemplos em diversos conjuntos habitacionais a partir do estudo de seus projetos e do contexto de suas construções, tendo como ponto de partida o conjunto soviético Narkomfin (1928) e a difusão das ideias da habitação mínima no contexto nacional e internacional. Foram levantados os projetos dos conjuntos e dos apartamentos - no recorte temporal de 1920 a 1960 - de maneira a compreender a ênfase dada em cada setor da casa e como as ideias se concretizaram ao longo das décadas e em contextos culturais diferentes. Propõe-se ainda estabelecer um percurso dos formatos dessa tipologia, compreendendo o contexto de circulação de ideias, transformações e adaptações a contextos culturais variados.

PALAVRAS-CHAVE: Arquitetura moderna. Habitação. Domesticidade. Projeto.

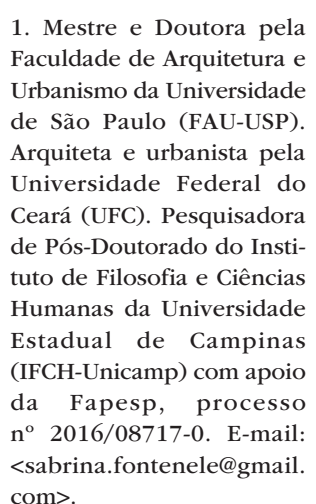
com>. 
2. Eric Mumford (2000) questiona a ideia de um movimento moderno unitário na arquitetura e chama a atenção em seu livro para a variedade de discursos apresentados nos primeiros congressos de arquitetos modernos, demonstrando inclusive como os bastidores desses eventos revelam os apagamentos realizados na historiografia. A definição de arquitetura moderna utilizada neste artigo se baseia nos princípios de racionalidade construtiva das formas arquitetônicas, na busca de eficiência funcional e climática. Foram utilizadas como referências teóricas as análises de autores internacionais como Argan (1992), Frampton (2000), Cohen (2013) e Gorelik (2005), e nacionais, entre os quais Anelli (2001), Lira (2011), Segawa (1999), entre outros.

3. Ver Cohen (2013) e Frampton (2000).
ABSTRACT: This paper proposes to understand how the idea of modern life came about in the architectural exploits of the modernist movement, with duplex apartments as an object of analysis. The spatial arrangements linked to the duplex typology were originally related to the idea of economy in construction and to modernist discourse on the functionality of spaces, which pointed to new domestic practices by considering women's foray into the labor market and their reduced role in the organization of home and family. Examples from various housing complexes were analyzed from the standpoint of the building's projects and the context of their construction. The starting point was the Soviet building Narkomfin (1928) and the diffusion of the ideas of minimal housing in the national and international context. Housing complexes and apartment projects from the 1920-1960 time period were surveyed, in order to understand the emphasis given to each section of the house and how, over the decades, the underlying ideas materialized in different cultural contexts. This paper also proposes to establish a format course of the duplex typology, encompassing the circulation of ideas, transformations, and adaptations to different cultural contexts.

KEYWORDS: Modern architecture. Housing. Domesticity. Design.

\section{O MORAR MODERNO}

A morada foi objeto de debate e experimentação projetual frequente entre os arquitetos. Entre aqueles vinculados ao movimento moderno de arquitetura, ${ }^{2}$ muitas vezes o tema da habitação propiciou tentativas de desenvolver novos arranjos espaciais que incentivassem novas práticas domésticas e garantissem uma vida mais saudável e estimulante.

No contexto europeu, esse interesse se vinculava diretamente à carência de espaços habitáveis em cidades transformadas já no século XIX, pelo impacto da Revolução Industrial e seu consequente crescimento populacional - fruto de um grande número de pessoas que migraram para as cidades em busca de oportunidades -, além da destruição provocada pela Primeira Guerra Mundial no início do século XX. ${ }^{3}$ Um dos objetivos dos arquitetos e urbanistas neste período era a construção de espaços que colaborassem no melhoramento das cidades e nas 
condições de vida de seus habitantes. No Brasil, ainda nas primeiras décadas do século XX, os edifícios construídos no contexto de modernização das cidades apresentavam as novas possibilidades de desenho e organização espacial, acomodando novos programas que se instauravam com o crescimento das atividades terciárias.

fortalecimento da indústria possibilitaria aos arquitetos vinculados ao movimento moderno o uso de outras técnicas construtivas a partir de novos materiais como aço, concreto e vidro, que garantiam boa iluminação, insolação e ventilação nos cômodos, alturas cada vez maiores dos edifícios e integração entre os espaços.

A ruptura com o passado e a possibilidade de pensar novas formas de moradia condizentes com a ideia do "homem moderno" será reforçada em vários lugares no início do século XX. Le Corbusier defendeu a casa como "máquina de morar", enquanto na Alemanha arquitetos, designers e outros estudiosos refletiam sobre a demanda de habitação dos conjuntos coletivos, que se diferenciavam da casa burguesa tradicional pelo uso de técnicas industriais de produção, pelo cuidado com insolação e ventilação natural e pela inovação em termos de organização espacial.

Em 1927, a exposição da Deutcher Werkbund em Stuttgart, organizada por Mies van der Rohe, reuniu arquitetos de várias partes da Europa para apresentar análises e projetos para um novo conceito do morar. ${ }^{4}$ Os projetos da Weissenhofsiedlung, construídos em terrenos municipais, foram concebidos como um bairro com habitações de diversos tipos: unifamiliar isolada e geminada, em banda e blocos de apartamentos que apresentavam o emprego de materiais industrializados e a inovação de sistemas construtivos. $\bigcirc$ pôster de divulgação da amostra, desenhado por Willi Baumeister, trazia as frases "Como deveríamos viver? A habitação" tendo como fundo uma sala riscada, reforçando a ideia de negação dos padrões de morar do século XIX. Essa exposição é apenas um exemplo das tentativas de discutir a moradia que, vinculada ao processo de industrialização, poderia suprir a demanda habitacional das metrópoles europeias.

Neste contexto, arquitetos, engenheiros, reformadores sociais analisaram os cômodos das casas, os movimentos dos membros das famílias em seus espaços e os mobiliários existentes para lançar novos arranjos a um custo cada vez menor. A discussão cada vez mais frequente entre os profissionais se deu em congressos, palestras, exposições, revistas e periódicos, saindo do contexto europeu e se espalhando pelos diversos continentes.

No Brasil, muitas das propostas europeias foram discutidas e analisadas pelos estudantes de arquitetura e de engenharia, e entre a classe profissional que
4. Ao todo participam dezesseis arquitetos modernos: onze alemães (Adolf Rading, Adolf Schneck, Bruno Taut, Hans Poelzig, Hans Scharoun, Ludwig Hilberseimer, Max Taut, Mies van der Rohe, Peter Behrens, Richard Döcker e Walter Gropius); um belga (Victor Bourgeois); dois holandeses (J. J. P. Oud e Mart Stam); um austríaco (Josef Frank); e um suíço (Le Corbusier). 
5. Ver Bonduki e Koury (2014), Botas (2016), Bruna (2015), Rossetto (2002), Sampaio (1998), Silva (2013) e Villa (2002).

6. Cf. Rossetto (2002, p. 138).

7. Carlos Lemos (1976) utiliza em seu livro o seguinte esquema funcional de uma moradia: estar, repouso noturno e serviço. Aqui utilizaremos a nomenclatura que classificaria os setores como íntimos (dormitórios, banheiros privativos, varandas íntimas), social (salas de jantar, estar, varandas) e de serviço (cozinha, copa, lavanderia, dependências dos empregados) que foram diferenciados por cores nos desenhos.

8. Agradeço especialmente à Gabriela Piccinini pelo cuidado com a apresentação gráfica dos desenhos aqui apresentados. organizavam. Especialmente no Rio de Janeiro e em São Paulo, novos conjuntos de apartamentos traziam possibilidades para as diversas classes. Essa questão da habitação coletiva nas metrópoles foi abordada em trabalhos que demonstraram o esforço dos arquitetos modernos em projetar e construir habitações de qualidade, em quantidade e com custos mais baixos. ${ }^{5}$

\begin{abstract}
A produção da habitação na escala e nas características exigidas pela incorporação imobiliária não seria possível se não fosse empregados vários métodos como padronização de componentes arquitetônicos, produção em série, racionalização da distribuição dos espaços, entre outros princípios que permitiram que a moradia fosse produzida de forma mais econômica e atingisse um público até então fora do mercado imobiliário. ${ }^{6}$
\end{abstract}

No caso da demanda habitacional, iniciativas pioneiras estiveram associadas aos apartamentos duplex construídos em grandes conjuntos. Estes exemplares apresentavam uma otimização das áreas dos apartamentos a partir da distribuição setorial ${ }^{7}$ em níveis: íntimo, social e de serviços.

Este artigo se propõe a entender o que representa esta tipologia e como ela se transforma ao longo do tempo. Para tanto, as plantas dos conjuntos e dos apartamentos foram redesenhadas ${ }^{8}$ e analisadas segundo a lógica de três diferentes setores: áreas sociais, íntimas e de serviço. Assim, foi possível compreender a ênfase dada em cada área ou atividade nos projetos analisados. Os arranjos espaciais desta tipologia se relacionavam originalmente com a ideia de economia na construção e com o discurso da funcionalidade do espaço que sugeria novas práticas domésticas ao considerar a entrada da mulher no mercado de trabalho, como também sua participação na organização do lar e da família. A análise dos projetos aqui selecionados - no recorte temporal de 1920 a 1960 - tenta entender como as ideias se distribuíram ao longo das décadas e em contextos culturais diferentes. Assim, partimos do contexto europeu para nos aproximarmos das iniciativas latino-americanas, demonstrando o quanto elas se apropriam daquelas propostas e as transformam. Propomos ainda estabelecer um percurso dos formatos dessa tipologia, compreendendo o contexto de circulação de ideias, deslocamentos, transformações e adaptações a contextos culturais variados.

Os projetos foram entendidos como documentos e, depois dos levantamentos realizados em bibliotecas e arquivos, os desenhos foram analisados tentando informar e problematizar questões domésticas, sociais, artísticas e culturais. 


\section{HABITAÇÃO MÍNIMA E A DISSOLUÇÃO DO LAR BURGUÊS TRADICIONAL}

O conjunto soviético Narkonfim (1928-1930) é entendido como o primeiro edifício moderno que se utiliza da tipologia duplex, em uma tentativa de propor um novo modo de vida aos cidadãos russos, logo nas primeiras décadas depois da Revolução Soviética. Projetado pelo arquiteto russo Moisiei Guinzburg, ${ }^{9}$ então coordenador do Comitê de Construções Estatais, o conjunto materializava discussões, anseios e propostas dos arquitetos modernos soviéticos na década de 1920. Segundo Jean-Louis Cohen, os frequentes concursos davam forma a estas discussões, em que participavam tanto membros de entidades profissionais como arquitetos independentes. ${ }^{10}$ Neste sentido, os trabalhadores eram os destinatários das novas políticas urbanas e dos novos espaços arquitetônicos. Kopp afirma que, desde 1926, o Estado apoiava arquitetos e instituições de pesquisa que empreendiam metódicos estudos para definir programas e a expressões arquitetônicas de um novo tempo. ${ }^{11}$

A partir de 1928, o governo central tomou a responsabilidade de desenhar e construir a habitação para a classe operária. Neste mesmo ano, Ginzburg foi indicado para organizar e coordenar o órgão responsável por essas novas construções da República Soviética. Em três meses, seu grupo produziu cinco tipologias de unidades de habitação com diversas variações. Blizkanov aponta que Ginzburg já discutia e repensava com o grupo dos construtivistas as possibilidades de projetar e construir moradas para um novo modo de vida socialista. ${ }^{12}$ Segundo Cohen, "a fim de transformar os hábitos cotidianos, os edifícios deveriam ser o que denominavam de 'condensadores sociais', destinados a acelerar as mudanças na mentalidade da população". ${ }^{13}$

A "Casa Comunal" - bastante explorada e discutida pelos arquitetos do período - seria um complexo residencial com serviços integrados, que demonstraria a seus moradores como o modo de vida do trabalhador soviético se diferenciava daquele burguês tradicional. A proposta se baseava na libertação das mulheres dos trabalhos domésticos e da educação pública das crianças.

Sob o socialismo, o trabalho doméstico seria transferido para a esfera pública: as tarefas realizadas individualmente por milhões de mulheres não pagas em suas casas seriam assumidas por trabalhadores assalariados em refeitórios, lavanderias e creches comunitários. Só assim as mulheres se veriam livres para ingressar na esfera pública em condições de igualdade com os homens, desvencilhadas das tarefas de casa. ${ }^{14}$
9. Moisiei Yakovlevich Ginsburg foi um teórico e prático da arquitetura soviética. Seu artigo "Estilo e época”, de 1924 , repercutiu as ideias de Le Corbusier ao propor um novo método de projeto fundado no estudo das máquinas e na aplicação de seus dispositivos à arquitetura (Cohen, 2013). De 1923 a 1924, atuou em vários ciclos apresentando e defendendo suas ideias relacionadas ao movimento construtivismo (Khan-Mahomedov, 1971).

10. Cohen (2013, p. 165).

11. Cf. Kopp (1974).

12. Blizkanov (1993).

13. Cohen (2013, p. 166).

14. Goldman (2014, p. 21). 
15. Navailh (1995, p. 282).

16. Kopp (1974, p. 128).
Especialmente nas primeiras décadas, "a mulher obtém, desde logo, a igualdade total dos direitos civis. A organização comum das tarefas domésticas e a assunção pelo Estado da saúde e da educação dos filhos permitem-lhe trabalhar e ser economicamente independente". ${ }^{15}$ Os conjuntos habitacionais pensados neste momento buscavam, pela disposição dos apartamentos e da presença dos equipamentos coletivos, liberar a mulher trabalhadora das atividades do lar e estimular uma convivência mais intensa entre os habitantes.

Nesse período de forte modificação social, a arquitetura era entendida como uma ferramenta de transformação dos hábitos e que estimularia sentimentos de coletividade. Como diria Anatole Kopp, "la arquitectura tiene por objeto la edificación de un marco de vida nuevo que refleje las aspiraciones de la sociedad socialista y que pro su vez influya sobre la propia sociedad". 16 Ginzburg foi um grande defensor da ideia que a arquitetura tem a função de estimular a transformação de um novo modo de vida. Tendo em vista esta crença, propôs tipologias habitacionais variadas que visavam a dissolução da vida doméstica tradicional burguesa e a criação de apartamentos com um ou dois quartos, uma sala de estar com uma cozinha embutida e um lavatório (em alguns casos banheiros), espaços reduzidos onde os cidadãos teriam um pouco de privacidade. Suas análises levavam a crer que seria mais eficiente e econômico o empilhamento dos cômodos dos apartamentos em dois andares (chamado "Tipo F") do que seu tradicional alinhamento em um corredor. Para a integração das áreas, há a alternância da altura das lajes, formando o meio pavimento.

A oportunidade de projetar um conjunto habitacional que abrigasse os funcionários do Comissariado do Povo para Finanças em uma região central de Moscou colocou à prova anos de estudo sobre as tipologias habitacionais. A unidade F foi adaptada para o Narkomfin, desenhado em colaboração o estudante de arquitetura Ignatii Milinis. Além deste formato, é possível encontrar a tipologia $K$, com banheiro completo e uma cozinha compacta, destinadas a familiares em transição. $\bigcirc$ projeto tem uma orientação única, de modo a receber maior entrada de luz, com um corredor a cada três andares.

Suas células habitacionais tinham de 27 a $30 \mathrm{~m}^{2}$ (Figuras 1 e 2), e compunham espaços exíguos onde os solteiros ou as pequenas famílias desempenhariam as atividades que necessitavam de privacidade: relaxar, dormir, realizar sua higiene pessoal e sua vida sexual. Por outro lado, as atividades domésticas deveriam ser realizadas coletivamente nos grandes equipamentos (alocados em um outro volume): cozinha e sala de jantar coletivas, lavanderia, serviço de limpeza dos alojamentos, jardim de infância, ginásio esportivo, biblioteca e um terraço comunitário. Assim, impunha uma convivência intensa entre seus habitantes. 


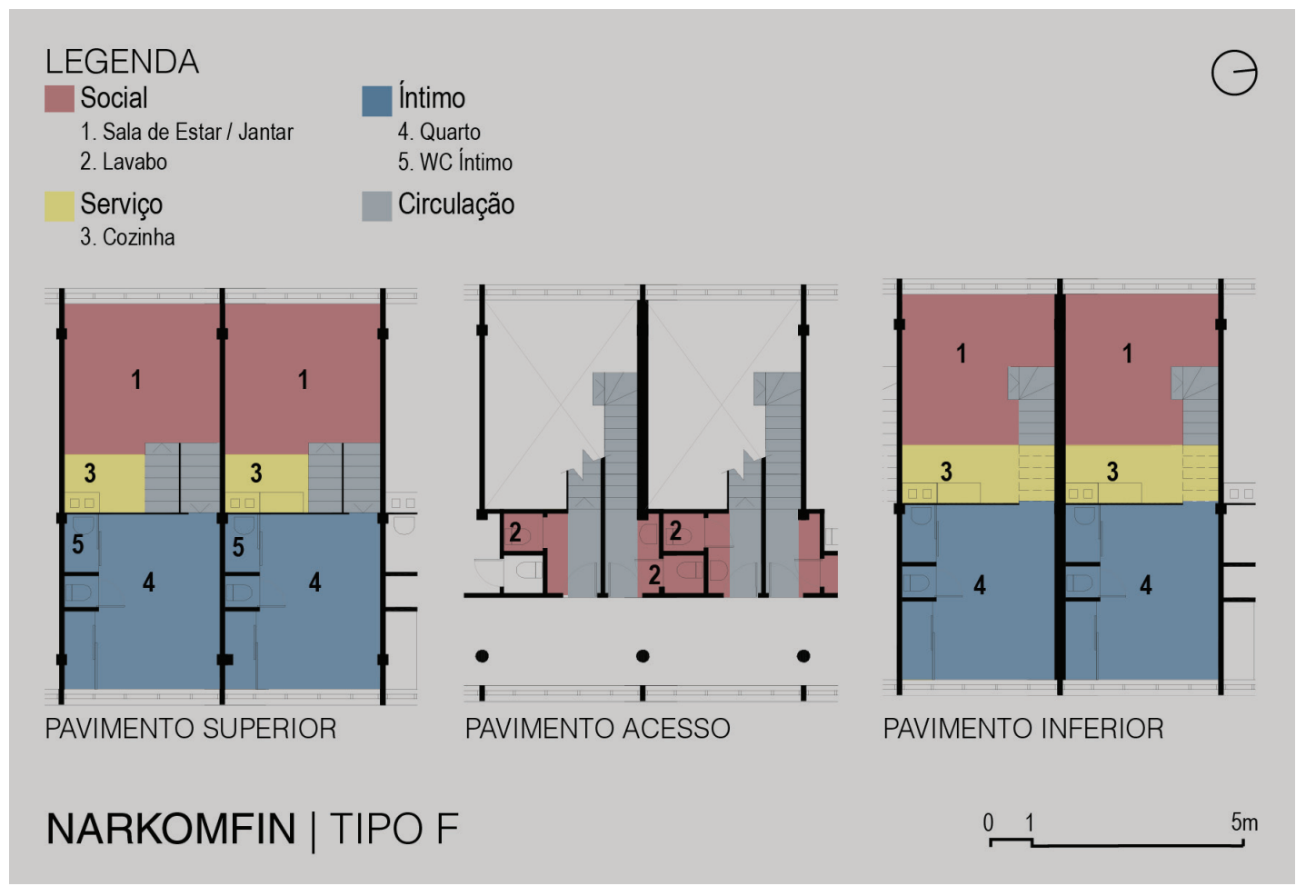

Figura 1 - Planta do Tipo F do Narkomfin. Desenho: Gabriela Piccinini e Sabrina Costa (2018)

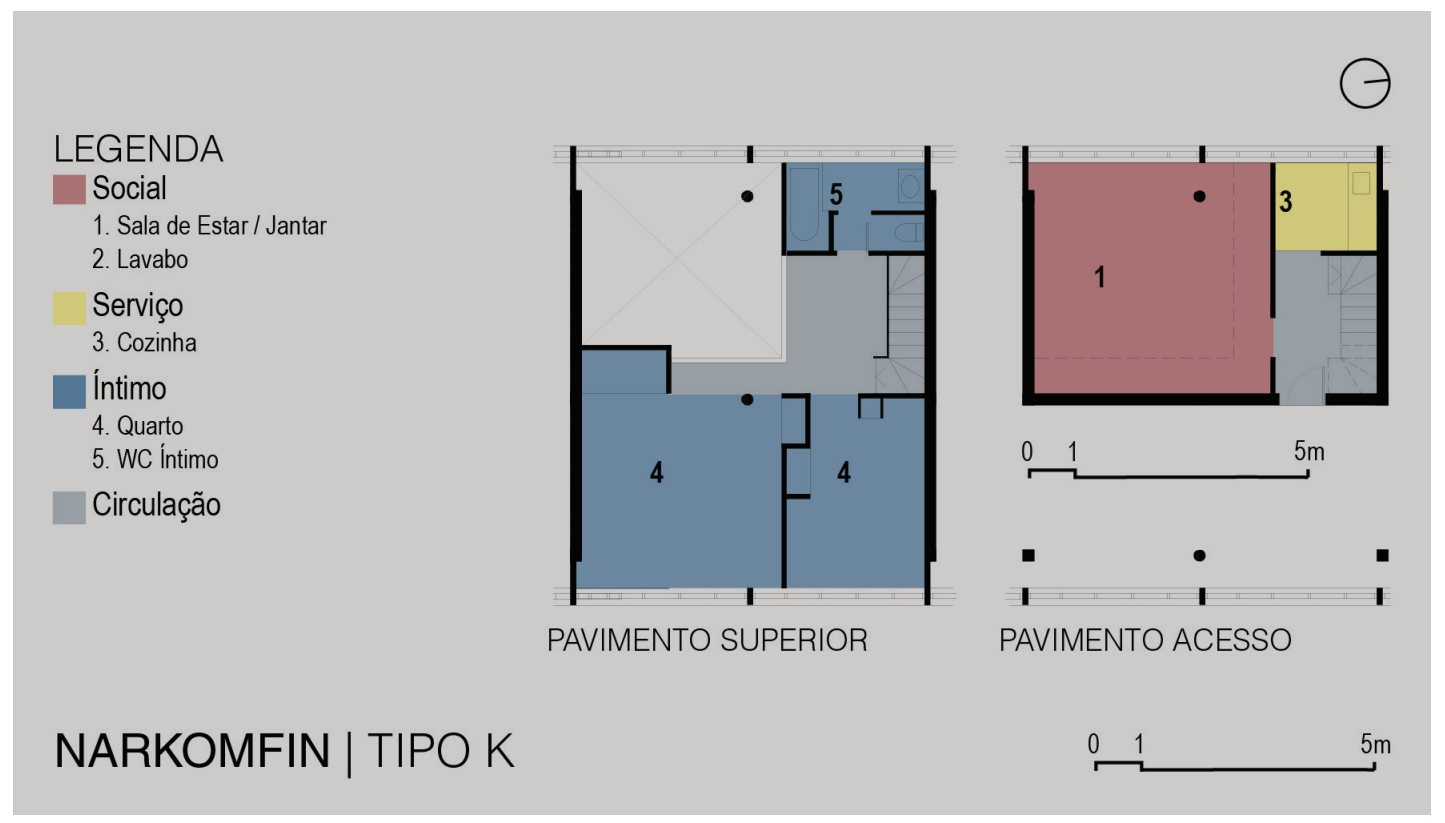

Figura 2 - Planta do Tipo K do Narkomfin. Desenho: Gabriela Piccinini e Sabrina Costa (2018) 
17. Cf. Bliznakov (1993) e Cohen (2013).

18. Cf. Tafuri (1984).

19. Curtis (2008, p. 249).

20. Cf. Mumford (2000).

21. Cohen (2013, p. 181).

22. Grette Schutte-Lihotzky ficou conhecida por sua cozinha, mas trabalhou com Ernst May no Departamento de Construção Municipal de Frankfurt em 1926 e teve diversas realizações na União Soviética, Turquia, Áustria e em vários outros países.

23. Rubino (2017, p. 175).
Convém informar que os arquitetos modernos soviéticos estavam atentos aos estudos sobre o espaço mínimo e a redução das áreas que os alemães vinham realizando nas primeiras décadas do século XX. ${ }^{17} \mathrm{Na}$ verdade, a intensa troca entre intelectuais e artistas alemães e soviéticos foi analisada por Tafuri ${ }^{18}$ ao tratar das relações entre as vanguardas artísticas, sociedade e a era da máquina. No caso da discussão sobre arquitetura, profissionais alemães e soviéticos da área também exerceram uma troca intensa ainda na década de 1920, atentos às publicações, exposições e manifestos onde eram divulgados os resultados de pesquisas teóricas e projetuais e recentes construções. Entre os germânicos, destacase a revista ilustrada Das Neue Frankfurt (1926-1930), que acompanhava as iniciativas que ocorriam em Frankfurt am Maim, divulgando-as como propaganda para várias partes do mundo.

Em 1925, o prefeito daquela cidade, Ludwig Landmann, convidou o arquiteto Ernst May para atuar em serviços de urbanismo e de obras, sendo designado Arquiteto da Cidade. May tinha a sua disposição o aparato público na desapropriação de terras para modernização urbana e uma equipe engajada em realizar pesquisas profundas sobre logísticas de uso e de produção industrial em todas as escalas, "dos espaços externos às habitações unifamiliares, e até os mínimos acessórios". ${ }^{19}$ Aproximadamente vinte conjuntos habitacionais foram construídos nos arredores de Frankfurt a partir das propostas de May e de seus associados. ${ }^{20}$

A ideia da nova Frankfurt se relacionava com a de uma nova vida (neue Leben), em que arquitetos, reformadores sociais e planejadores urbanos se empenhavam em propor uma realidade mais saudável, moderna e individual. Segundo Cohen, "a equipe de May ocupava-se também com a racionalização das ações domésticas segundo princípios tayloristas". ${ }^{21}$

Entre os membros da equipe de May estava Margarete Schutte-Lihotzky, ${ }^{22}$ responsável por diversos projetos, dentre os quais o desenvolvimento de uma cozinha mínima para ser usada nos conjuntos que ficou conhecida como "Cozinha de Frankfurt", e incorporava em seu desenho as questões de praticidade e higiene concernentes a este cômodo da casa.

A cozinha de Frankfurt, produzida industrialmente e instalada em onze mil apartamentos de trabalhadores, revelava uma cisão que em outras reformadoras sociais aparecia de maneira mais matizada: a cozinha era apenas para o trabalho, visto como um fardo para a dona de casa. Outros lugares da habitação poderiam oferecer conforto e relaxamento - e a segregação dos odores e ruídos do lugar de trabalho deveria garantir a qualidade dos espaços para se relaxar. ${ }^{23}$ 
Diante das pesquisas sobre habitação mínima e influenciada pela obra da americana Christine Frederick sobre a eficiência do trabalho doméstico, ${ }^{24}$ SchutteLihotzky se convenceu de que a luta das mulheres por independência econômica e desenvolvimento pessoal representava a racionalização dos trabalhos domésticos como uma necessidade absoluta. Mais uma vez a discussão sobre os espaços da vida doméstica recai sobre o papel das mulheres no cotidiano familiar e na possibilidade de libertá-las de horas enfadonhas em um ambiente pouco salubre. Assim, seus movimentos foram estudados e o desenho do mobiliário foi detalhado tendo em vista o cuidado com armazenamento, preparação e consumo dos alimentos, além da eficiência e rapidez dos trabalhos na cozinha.

$\bigcirc$ projeto do Schutte-Lihotzky representa a busca daquele momento por espaços salubres, que possibilitassem uma vida mais digna à população por meio de espaços compactos, objetivo que permeou a produção germânica do período. "Esse espírito investigativo parece ter entusiasmado arquitetos engajados com o Modernismo de outras partes da Europa, que o viram como evidência de que a tecnologia se afastava dos fins vorazes da economia laissez-faire e se voltava para fins socialmente responsáveis". ${ }^{25}$ Os arquitetos modernos soviéticos analisaram esta produção e tentaram incorporar várias das soluções sobre arquitetura mínima em seus projetos. ${ }^{26}$ É possível perceber no projeto do Narkomfin um diálogo direto com a questão da habitação mínima abordada pelos alemães, em um desdobramento concreto das possibilidades intrínsecas à realidade soviética.

De fato, o debate a respeito da habitação mínima foi tema do segundo Congresso Internacional de Arquitetura Moderna (CIAM) realizado em 1929 em Frankfurt. Eric Mumford - que analisou a fundo as discussões ocorridas em todos os encontros - informa que a decisão por esta cidade se deu pelo impacto da produção habitacional germânica da década de 1920. ${ }^{27}$ Assumindo como tema "A moradia para o mínimo da existência" (Die Wohnung für das Existenzminimum), os profissionais ali reunidos discutiram como resolver o problema da demanda habitacional a partir das novas lógicas construtivas, tecnológicas e domésticas. Os trabalhos coordenados por Ernst May ganharam destaque, inclusive com a realização de visitas em algumas das obras recentes na cidade.

Walter Gropius - que, assim como Le Corbusier, era uma das figuras mais atuantes dos CIAM - defendeu que, diante das mudanças nas dinâmicas familiares, algumas das funções exercidas pelas famílias deveriam ser relegadas ao Estado, de maneira que a mulher obtivesse mais liberdade para trabalhar e realizar outras atividades, inclusive remuneradas. Assim, o arquiteto alemão também defende que a organização espacial das casas parta de considerações biológicas, em que um espaço mínimo deve oferecer ar, luz e calor para seus membros. Mumford ainda
24. Christine Frederick (1883-1970) foi uma economista americana que desenvolveu uma pesquisa patrocinada pela revista Ladies' Home Journal em que tentou racionalizar o trabalho na cozinha. Nela, Frederick analisou cada uma das tarefas desenvolvidas, comparando o que acontecia neste cômodo com uma linha de montagem de uma fábrica, segundo Zabalbeascoa (2013). Entre os vários títulos publicados, destaca-se "The new housekeeping" (1913).

25. Curtis (2008, p. 249).

26. Cf. Bliznakov (1993).

27. Cf. Mumford (2000). 
28. Mumford (2000, p. 39).

29. Mumford (2000, p. 44).

30. Boesiger (1971). afirma que Gropius também conhecia as ideias soviéticas sobre a dissolução das famílias tradicionais burguesas e os novos arranjos arquitetônicos propostos pelos arquitetos modernos. "By perfecting the 'scientific solution' to the minimum dwelling, CIAM members believed that the collective dwellings envisioned in the Soviet Union and Germany could become economically feasible for mass housing". ${ }^{28}$ As ideias circulavam e ganhavam força entre os grupos, incentivando novos arranjos habitacionais que aliviassem o alto déficit habitacional europeu.

\section{LE CORBUSIER E A DISTRIBUIÇÃO DA CASA EM DOIS PAVIMENTOS}

A troca de ideias a partir dos eventos profissionais, das viagens e da circulação de publicações permite que os arquitetos conheçam e aprofundem a discussão sobre a habitação em diferentes contextos. Em 1930, Le Corbusier - que já tinha realizado algumas visitas à Rússia - sugere que a próxima edição do CIAM seja realizada em Moscou, tendo em vista a discussão e produção desenvolvidas pelos arquitetos soviéticos. ${ }^{29} \bigcirc$ impacto dessas visitas é visível em sua obra, especialmente nas relacionadas ao morar.

A discussão da habitação esteve presente ao longo da trajetória de Le Corbusier. Já no início da década de 1920, seu livro Vers une architecture apresentava a ideia da casa como máquina de morar. Em 1923 ele foi contratado pelo empresário Henri Frugès - que se interessou por suas ideias sobre padronização (standardização) - para construir casas para seus operários em Pessac, e assim o franco-suíço projetou sobrados de dois andares que ficaram conhecidos como Quartier Frugès.

A tipologia duplex foi utilizada pela primeira vez por Le Corbusier em 1930, quando ele e Pierre Jeanneret projetaram para o empresário suíço Edmond Wanner o "Inmeuble Clarté". $\bigcirc$ empreendimento em Genebra dispunha 48 apartamentos (sendo dezesseis deles duplex, ou como chamados por Le Corbusier, "appartements à double hauter"), alocados em um mesmo conjunto. ${ }^{30}$ Tratam-se, no entanto, de apartamentos com áreas maiores que visavam o lucro de seus empreendedores, sem a preocupação de abrigar um número maior de pessoas, de maneira econômica ao diminuir as áreas e oferecer equipamentos coletivos, como aqueles analisados anteriormente.

O exemplo mais famoso do uso dos apartamentos duplex na obra do arquiteto foi a Unidade de Habitação de Marselha (1946-1952). O conjunto foi desenvolvido sob influência direta da experiência soviética enquanto possibilidade de habitação em grande escala inserida no contexto de grande déficit habitacional do pós-Guerra, 
por encomenda do então Ministro da Reconstrução e do Urbanismo, Raoul Dauntry. ${ }^{31}$

Seus 337 apartamentos estão distribuídos em uma lâmina de cem metros de comprimento por trinta de largura, repetida em quinze andares. Os apartamentos duplex se alongam de leste a oeste e são acessados a cada três andares por corredores, assim seguindo o modelo do "Tipo F" proposto pelos arquitetos soviéticos, buscando economia na construção e aproveitamento máximo das áreas internas.

Os apartamentos apresentam possiblidades de organização variadas, mas um modelo de duplex se repete em mais de duzentas unidades lque tinham em geral $98 \mathrm{~m}^{2}$ ). $\bigcirc$ acesso se dá pela região próxima à cozinha e o morador pode descer ou subir um lance de escadas para se chegar aos dormitórios. No caso dos apartamentos onde os dormitórios se encontram no pavimento inferior, as salas estão integradas e uma varanda se abre para esta área social. Nos apartamentos cujos dormitórios estão no pavimento superior, as salas de jantar e de estar se encontram em pavimentos diferentes (Figura 3).

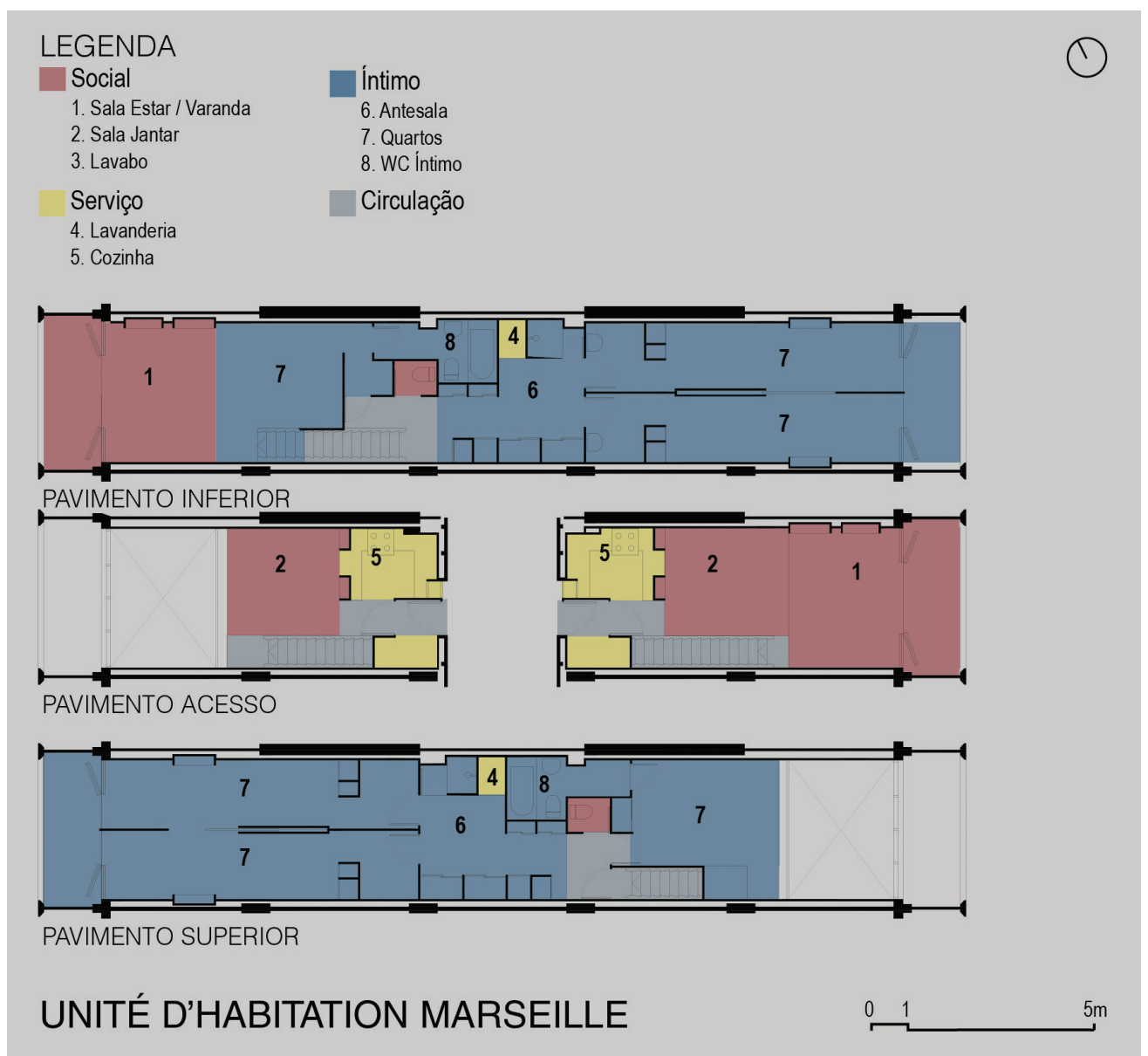

Figura 3 - Plantas dos apartamentos na Unidade de Habitação de Marselha. Desenho: Gabriela Piccinini e Sabrina Costa (2018) 
32. As fotografias analisadas foram consultadas no Centro de Estudo de Arquitetura e Design do Museu de Arte Moderna de Nova Iorque (Architecture and Design Study Center, MoMA).

33. Cf. Garay (2002)
Assim como no conjunto soviético, diversas atividades urbanas coletivas foram propostas no próprio conjunto: comércio, serviço, recreação e educação, distribuídas entre 0 terraço e outros andares. Seu $17^{\circ}$ andar conta com uma creche, enquanto seu terraço-jardim abriga equipamentos esportivos e recreativos, além de uma piscina rasa. No entanto, a ideia contrasta com os exemplos soviéticos ao voltar para dentro dos apartamentos os espaços de preparo e consumo das refeições e acolher a vida familiar em suas salas e varandas amplas.

O projeto da cozinha dos apartamentos da Unidade de Marselha foi desenvolvido por Charlotte Perriand, mostrando-se fundamental para propor arranjos modernos em espaços reduzidos. Em uma área de 4,8 $\mathrm{m}^{2}$ implantava-se uma cozinha em formato de "U", que dispunha às famílias os equipamentos necessários para o armazenamento e preparo dos alimentos e limpeza dos utensílios e louças, utilizando aço inoxidável nas bancadas, cores nos mobiliários e integrando a cozinha com a sala a partir de uma abertura. Novamente os espaços são pensados para tornar a vida doméstica mais prática e menos cansativa, aliviando as vidas das mulheres nas tarefas cotidianas do lar. Vale ressaltar que alívio que não significa liberdade total destas obrigações - prova disto são as fotografias regularmente apresentadas dos interiores desses apartamentos duplex, em que as mulheres comumente são registradas costurando, cuidando das crianças, na cozinha ou olhando a paisagem pela varanda, como analisaremos posteriormente neste artigo. ${ }^{32}$

Além de Marselha, outras três Unidades de Habitação foram construídas na França seguindo a lógica espacial daquela de Marselha: Nante-Rezé (1952), Briey-en-Forêt (1 959) e Firminy (1960). Eram edifícios de grandes dimensões, com equipamentos coletivos em seus interiores e apartamentos duplex organizados pela lógica do "Tipo F".

O impacto da construção da Unidade de Habitação de Marselha e da organização de seus apartamentos influenciou arquitetos nas realidades mais variadas. No México, o Conjunto Multifamiliar Miguel Alemán é um dos casos diretamente influenciados pelas ideias e propostas de Le Corbusier. Projetado pelo arquiteto Mario Pani, foi financiado pela Dirección de Pensiones Civiles y de Retiro e destinado aos trabalhadores do Estado, tratando-se do primeiro conjunto de renda moderada. ${ }^{33}$

O complexo abriga aproximadamente cinco mil pessoas 11080 apartamentos), formando uma comunidade unida e independente ("cidades autossuficientes"). Pani defendia que a concentração ordenada de gente e de 
serviços contribuiria, a longo prazo, para o crescimento regulado e racional da cidade. ${ }^{34}$ Assim, o complexo é formado por seis edifícios baixos, de três pavimentos, e nove altos, com treze pavimentos. Entre seus equipamentos, destacam-se uma escola com capacidade para seiscentos alunos, lavanderia, creche, postos médicos, cassino e espaços esportivos.

Em geral, os apartamentos duplex são organizados da seguinte maneira: no pavimento inferior se encontram cozinha e sala de jantar, enquanto o superior abriga sala íntima, banheiro e quarto (Figuras 4 e 5). Nos edifícios altos, a parada de elevador ocorre a cada três andares, assumindo a proposta do "Tipo F".

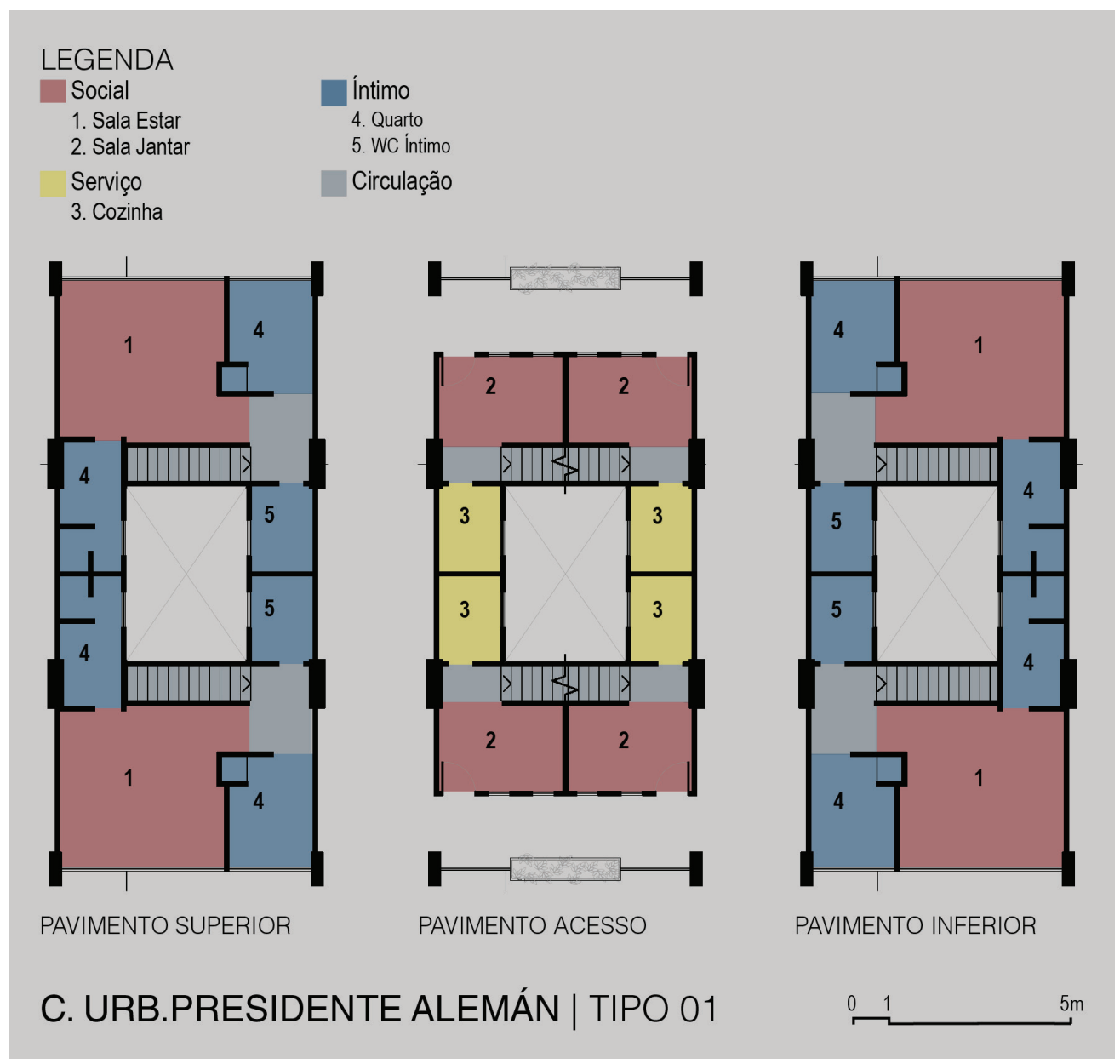

Figura 4 - Planta do Tipo 1 do Conjunto Funcional Presidente Alemán. Desenho: Gabriela Piccinini e Sabrina Costa (2018) 
35. Roberto e Roberto (1939, p. 628).

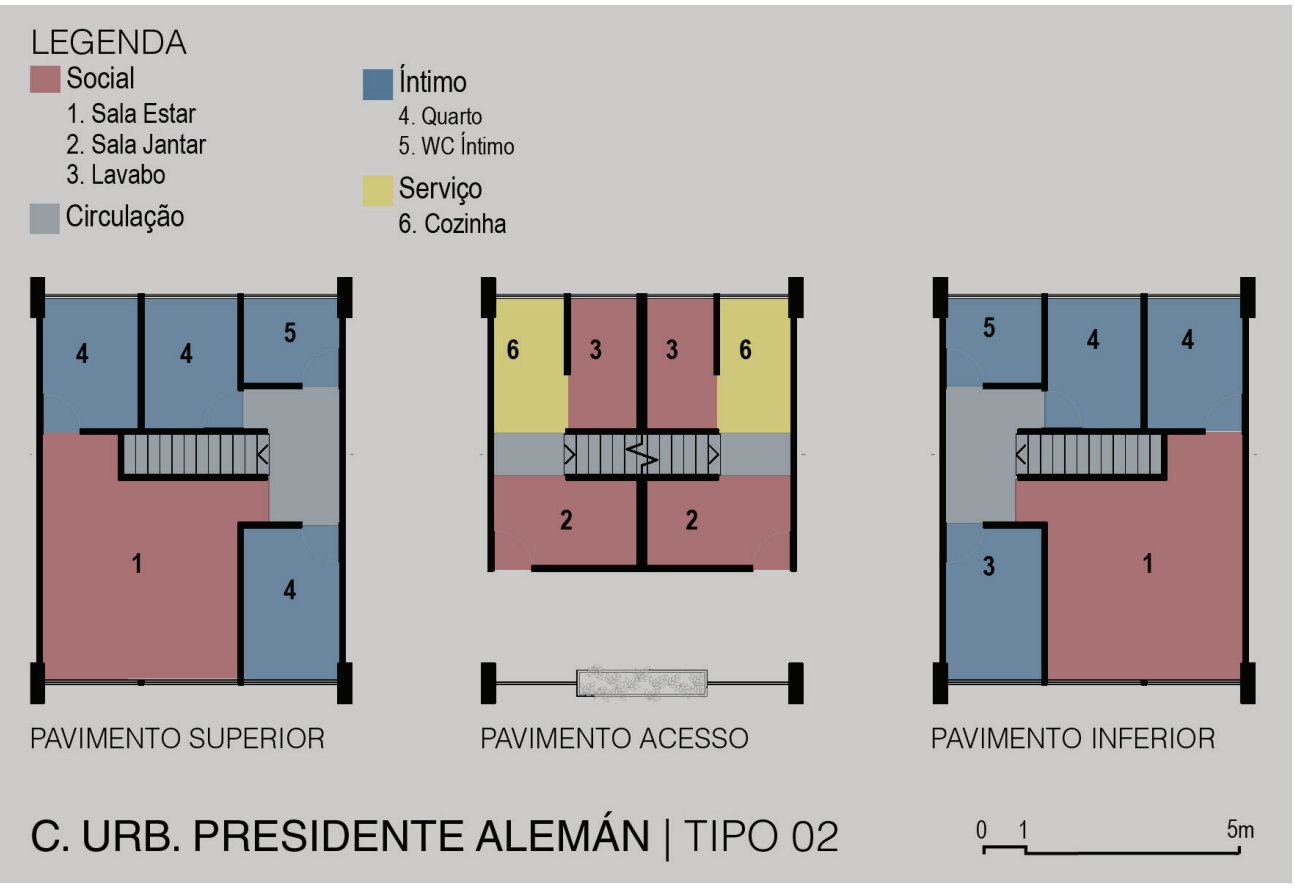

Figura 5 - Planta do Tipo 2 do Conjunto Funcional Presidente Alemán. Desenho: Gabriela Piccinini e Sabrina Costa (2018)

\section{A CHEGADA E CONSOLIDAÇÃO DA TIPOLOGIA NO BRASIL}

A discussão da habitação mínima ganhou força nos Congressos Internacionais de Arquitetura Moderna (CIAM) e chegou ao Brasil influenciando diretamente os arquitetos da Escola de Belas Artes do Rio de Janeiro. Na antiga capital federal, ainda na década de 1930, o escritório formado pelos irmãos Marcelo e Milton Roberto propôs, construiv e divulgou o primeiro empreendimento com esta tipologia, o Edifício Santo Antônio do Morro, na região central do Rio de Janeiro. Segundo os autores do projeto,

As vantagens do apartamento de pavimento duplo são patentes. [...] Para o proprietário, além do aumento de habitações alugáveis, a economia do custo e do consumo dos elevadores (redução de cincoenta (sic) por cento do número de paradas e aumento da eficiência do serviço), e da conservação e iluminação elétrica dos halls e galerias, reduzidos para a metade. ${ }^{35}$

O projeto desenvolvido por Marcelo e Milton Roberto foi encomendado pela iniciativa privada em 1929. Em seu térreo implantaram-se algumas lojas voltadas para a rua do Lavradio, enquanto os 48 apartamentos duplex se organizam em quatro volumes interligados por uma circulação interna. Os arquitetos 
justificam a escolha da tipologia duplex pelo aumento do número de unidades distribuídas, pela economia de elevadores e pela conservação do sistema de iluminação elétrica das galerias. Publicado na revista Arquitetura e Construção de 1939, os arquitetos iniciam seu texto de apresentação explicando que não se trata de uma invenção deles, mas de uma solução já utilizada pelos russos. ${ }^{36}$

$\bigcirc$ conjunto oferece dois tipos diferentes de apartamentos duplex. A grande maioria apresenta no pavimento inferior sala e cozinha de tamanhos reduzidos e, no superior, dois dormitórios e um pequeno banheiro. Os apartamentos voltados para a rua do Lavradio possuem balcões com um desenho que remete ao do conjunto de dormitórios dos alunos da Bauhaus e criam um ritmo interessante na fachada. A outra tipologia consiste em apartamentos com áreas ainda mais exíguas e que não apresentam cozinha em sua organização (Figura 6).

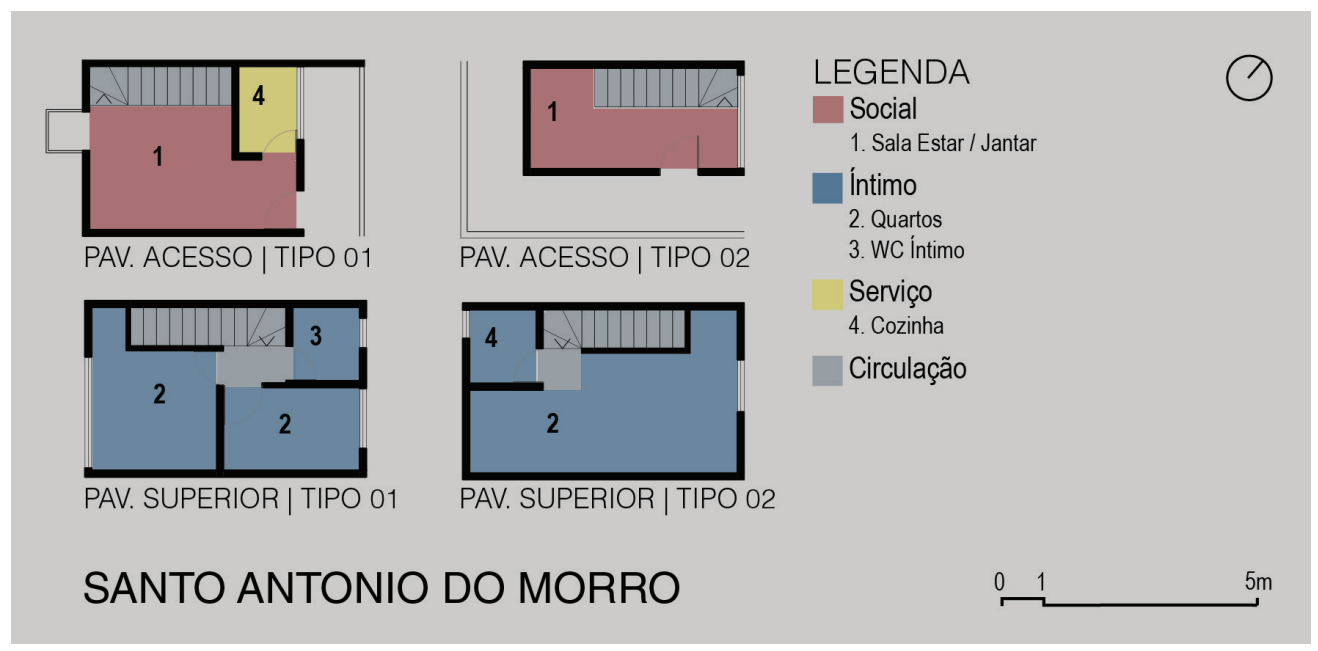

Figura 6 - Planta dos tipos 1 e 2 do Conjunto Santo Antonio do Morro. Desenho: Gabriela Piccinini e Sabrina Costa (2018)

Em 1941, Marcelo e Milton Roberto projetaram outro conjunto que se utilizava da tipologia duplex, desta vez na cidade de São Paulo. Financiado pelo Instituto de Aposentadoria e Pensões dos Industriários (lapi), o edifício Anchieta foi o primeiro conjunto vertical na Avenida Paulista e constitui-se de térreo com comércio, sobreloja, onze lâminas com apartamentos e terraço-jardim. Das oitenta unidades habitacionais, doze são do tipo duplex.

A promoção deste edifício mostra a ambiguidade da atuação habitacional dos IAP. Situado em uma região nobre de São Paulo, no entroncamento de três importantes avenidas (Paulista, Consolação e Angélica), ele foge aos padrões de dimensão e acabamento adotados na produção de habitação social do lapi. ${ }^{37}$
36. Cf. Roberto e Roberto (1939).

37. Bonduki, Silva e Koury (2014, p. 84). 
Seus apartamentos duplex voltam-se para a avenida Angélica e organizamse em duas diferentes plantas, embora com disposição semelhante dos cômodos. Seus pavimentos ímpares apresentam sala, hall, cozinha e quarto de empregada, enquanto os pares têm três dormitórios e um banheiro. Cada pavimento apresenta entradas definidas: nos andares pares, o acesso à lavanderia é uma entrada de serviço, enquanto nos ímpares se encontra a entrada principal do apartamento (Figuras 7 e 8). A lavanderia não tem acesso direto aos dormitórios, mas se liga à cozinha por uma escada.

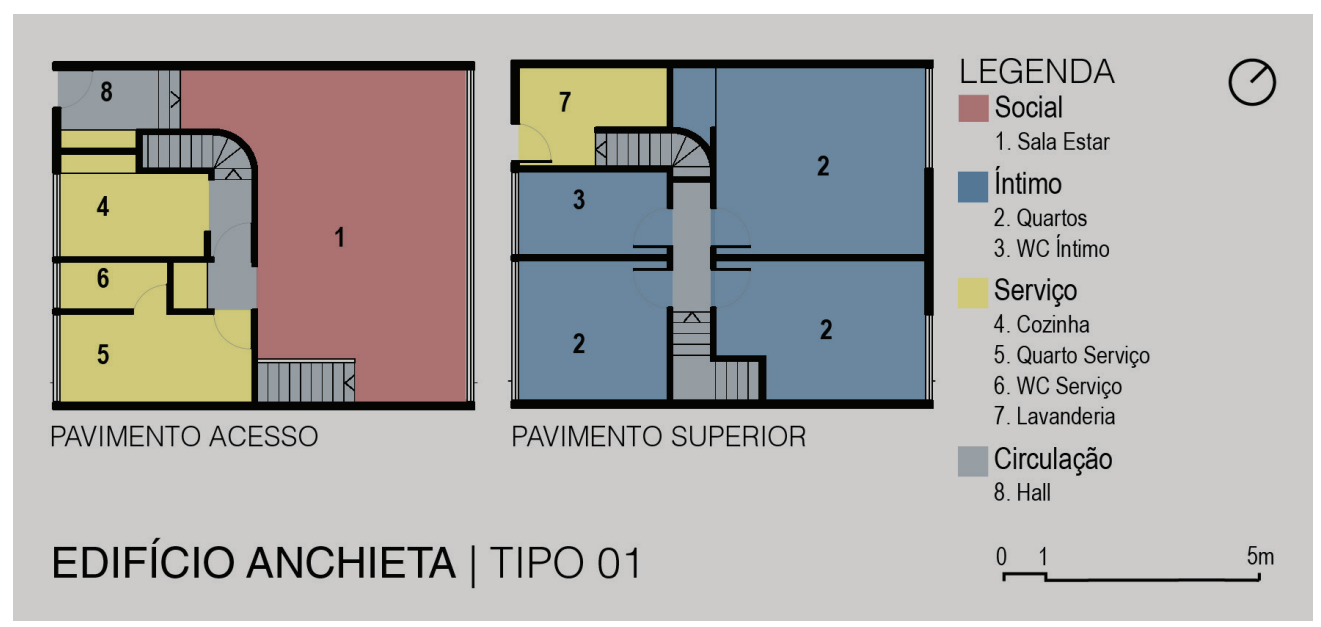

Figura 7 - Planta do Tipo 1 do Edifício Anchieta. Desenho: Gabriela Piccinini e Sabrina Costa (2018)

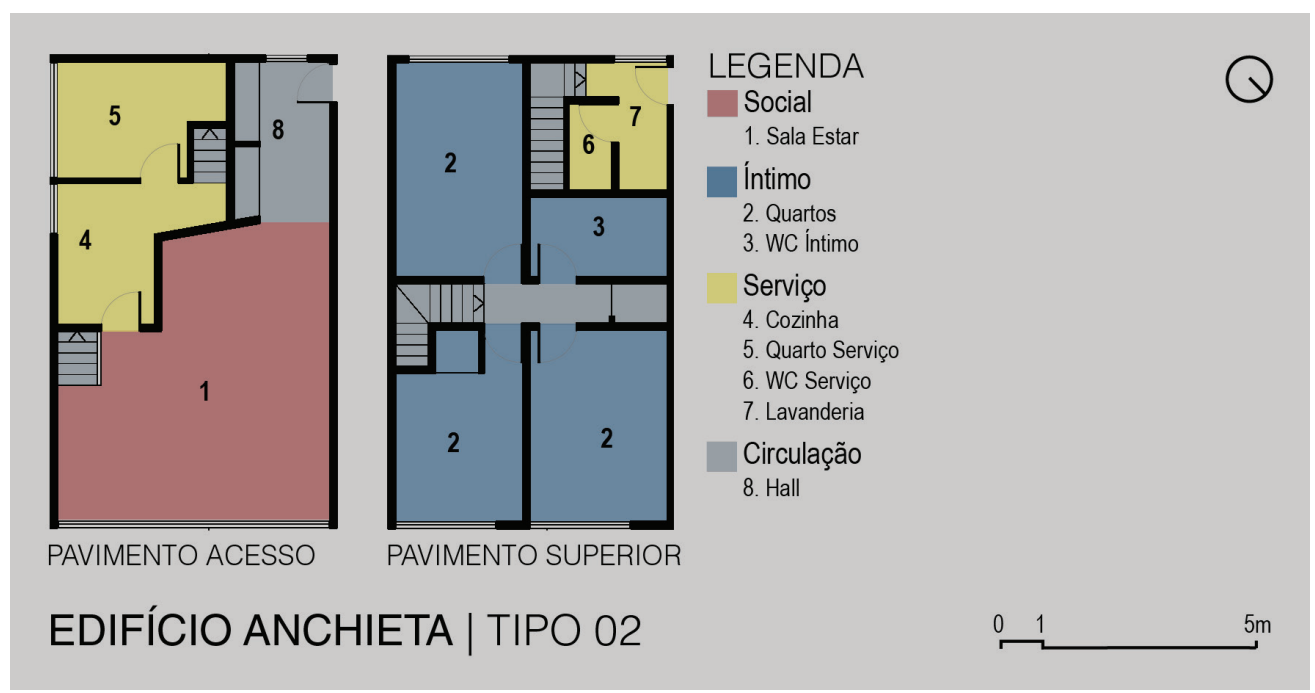

Figura 8 - Planta do Tipo 2 do Edifício Anchieta. Desenho: Gabriela Piccinini e Sabrina Costa (2018) 
Esta tipologia duplex foi utilizada e repensada pelos irmãos Roberto em vários empreendimentos, possibilitando transformações na planta e na disposição das áreas de cada conjunto, especialmente no que se refere a circulações e acessos. Se no edifício Santo Antônio do Morro - assim como ocorria no Narkomfin - os corredores de circulação estão presentes apenas nos apartamentos de andares ímpares, garantindo assim a ocupação dos espaços acima dos corredores por outros cômodos, a repetição dos corredores nos andares do Anchieta busca garantir acessos diferentes às diferentes classes sociais.

Em outro consagrado exemplar carioca, o edifício Julio de Barros Barreto (1947), os acessos às áreas principais e às de serviço também são separados por pavimento, sendo esta demarcação ainda mais intensa pela parada dos elevadores, como será apresentado a seguir. Os andares pares se configuram como espaços voltados aos empregados que trabalham e/ou vivem nos apartamentos, enquanto os ímpares são destinados às áreas sociais.

conjunto se implanta em um terreno acidentado com uma bela vista de Botafogo, onde seus oitenta apartamentos se distribuem em duas lâminas 140 e 65 metros de comprimentol com dez pavimentos, sendo todas as unidades duplex. Sua composição volumétrica, além do uso de cores e de materiais diferentes, se destaca na paisagem urbana. Com relação à organização interna, dois tipos de apartamento têm disposições semelhantes: no pavimento térreo há sala (aberta para uma varanda em um tipo, fechada em outro), cozinha e quarto de empregada; no pavimento superior, dormitórios, lavanderia e banheiro. Um dos quatro elevadores tem abertura apenas para os pavimentos pares, no mesmo andar que se encontra a lavanderia dos apartamentos (Figuras 9 e 10). Assim, estabelecem-se duas áreas de circulação independentes: as sociais e as de serviço.

A maioria esmagadora dos planos prevendo diferenciação de circulações autoriza-nos a generalizar dizendo que, ao contrário dos projetos de outros países, o apartamento brasileiro caracteriza-se pela dupla entrada, pela previsão de dois acessos, o nobre e o de serviço, e pela instalação de elevadores separados para cada caso. ${ }^{38}$

A própria presença dos quartos de empregada nos apartamentos atesta que o edifício se volta para um público diferente daquele da área central, questão que também será desenvolvida adiante neste artigo. Assim como o edifício Anchieta, o conjunto foi construído a partir da demanda do poder público, no caso o Instituto de Previdência e Assistência dos Servidores do Estado (lapase). 


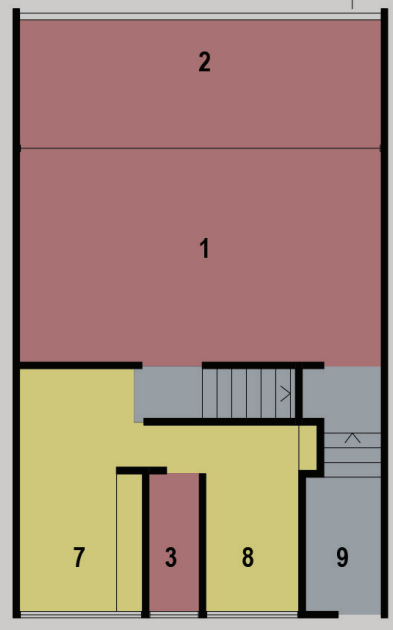

PAVIMENTO ACESSO

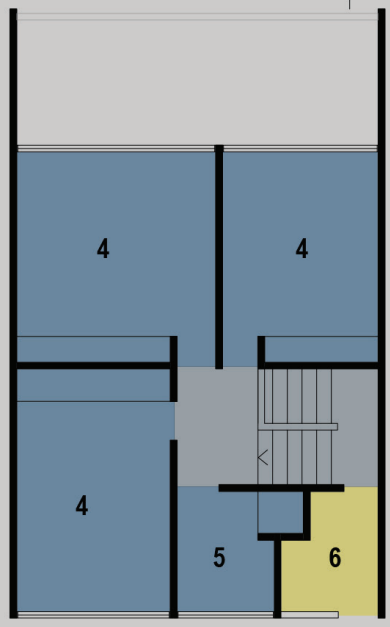

PAVIMENTO SUPERIOR

\section{LEGENDA \\ Social \\ 1. Sala Estar \\ 2. Varanda \\ 3. Lavabo \\ Íntimo \\ 4. Quartos \\ 5. WC Íntimo \\ Serviço \\ 6. Lavanderia \\ 7. Cozinha \\ 8. Quarto Serviço \\ Circulação \\ 9. Hall}

\section{JULIO DE BARROS BARRETO | TIPO 01}

Figura 9 - Planta do Tipo 1 do Julio de Barros Barreto. Desenho: Gabriela Piccinini e Sabrina Costa (2018)

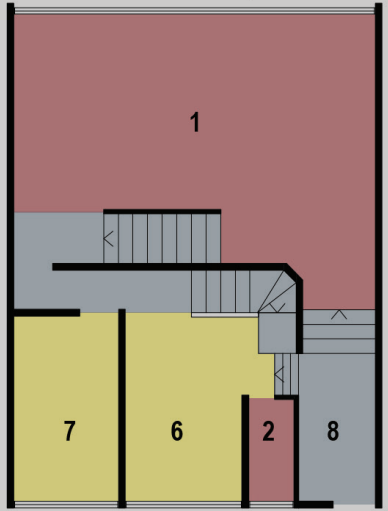

PAVIMENTO ACESSO

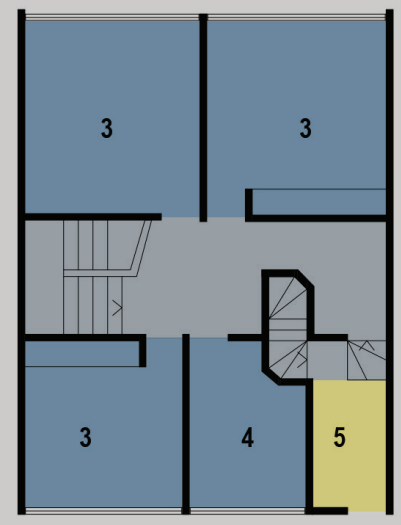

PAVIMENTO SUPERIOR
LEGENDA

Social

1. Sala Estar

2. Lavabo

Íntimo

3. Quartos

4. WC Íntimo

Serviço

5. Lavanderia

6. Cozinha

7. Quarto Serviço

Circulação

8. Hall

\section{JULIO DE BARROS BARRETO | TIPO 02}

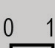

$5 \mathrm{~m}$

Figura 10 - Planta do Tipo 2 do Julio de Barros Barreto. Desenho: Gabriela Piccinini e Sabrina Costa (2018) 
Uma análise da coleção de fotos referentes a este empreendimento revela imagens em preto e branco da obra no momento da construção e logo que finalizada, das paisagens do Rio de Janeiro e do térreo do edifício. ${ }^{39}$ Nenhuma das dezenas de fotografias apresenta os interiores dos apartamentos ou sua ocupação. $\bigcirc$ mesmo ocorre nas publicações que tratam da obra, que optam por enfatizar as dimensões do conjunto e sua implantação, em vez de apresentar a proposta de morar daqueles apartamentos. A possível leitura acerca desta se dá a partir das plantas apresentadas nos poucos livros que tratam da obra dos irmãos Roberto.

Enquanto na etapa de elaboração do projeto e de construção do edifício da rua do Lavradio o escritório era formado pelos irmãos Marcelo e Milton Roberto, em 1947, quando o edifício Julio Barros Barreto foi projetado, Maurício Roberto já fazia parte da sociedade dos irmãos. ${ }^{40} \mathrm{~A}$ ideia dos Roberto para a construção de um conjunto de apartamentos duplex em área mínima tem influência direta das leituras, descobertas e discussões que ocorriam na Escola Nacional de Belas Artes no período em que os irmãos ali estudaram. ${ }^{41}$ Essa tipologia foi utilizada por esses arquitetos em vários outros empreendimentos, entre eles os edifícios Angel Ramírez (Rio de Janeiro, 1952), Finúsia e Dona Fátima (Rio de Janeiro, 1952) e Sambaída (Rio de Janeiro, 1952), além do projeto não construído para o Conjunto Residencial da Penha (Rio de Janeiro, 1937). ${ }^{42}$

Como demonstrou a pesquisa "Pioneiros da Habitação", ${ }^{43}$ os Institutos de Aposentadorias e Pensões foram responsáveis por uma intensa produção habitacional brasileira do século XX. Neste sentido, vários empreendimentos se utilizaram da ideia dos apartamentos duplex para propor conjuntos coletivos com qualidade, funcionalidade e economia.

Na área central de São Paulo, por iniciativa do Instituto de Aposentadoria e Pensões dos Industriários (lapi) foi construído o conjunto Japurá loficialmente Conjunto Residencial Armando de Arruda Pereira), em uma região onde se localizava o cortiço conhecido como Navio Parado. ${ }^{44}$

Projetado em 1945 pelo arquiteto Eduardo Kneese de Mello,o conjunto Japurá marcou a paisagem pela presença de torres-lâminas de habitação. Enquanto a mais baixa é composta por quitinetes destinadas a jovens solteiros e comércio, a grande torre tem catorze pavimentos e abriga 288 unidades habitacionais duplex, que propiciam a divisão entre espaços íntimos e sociais e permitem grandes economias na construção. ${ }^{45}$

Os apartamentos duplex distribuem suas áreas sociais nos andares inferiores (sala, cozinha, despensa e hall da escada), enquanto os superiores abrigam dois quartos e banheiro. $\bigcirc$ arquiteto optou pela instalação de um pequeno tanque de lavar roupa nos banheiros de maneira a economizar espaço naquelas áreas consideradas de serviço (Figura 11 ).
39. Parte do conjunto de fotografias e desenhos pertencentes ao escritório dos irmãos Roberto está hoje salvaguardado Núcleo de Pesquisa e Documentação da Faculdade de Arquitetura e Urbanismo da Universidade Federal do Rio de Janeiro e foi consultado pela pesquisadora em outubro de 2017.

40. Segundo Luiz Felipe de Souza, "Marcelo esteve presente [no escritório] de 1936 a 1964, Milton de 1936 a 1953, e Maurício, de 1942 a 1996" (Souza, 2014, p. 64).

41. Com formações acadêmicas diferentes, determinadas pelo período de intenso debate entre modernos e neocoloniais na direção da escola, o perfil diferente dos três arquitetos possibilitou soluções variadas nas décadas de atuação da empresa conhecida como MMM Roberto. Souza (2014, p. 64) explica que a formação de Marcelo (o mais velho dos irmãos) ocorreu num período ainda mais conservador da Escola Nacional de Belas Artes; enquanto Milton acompanhou a proposta de Lucio Costa para a reformulação do currículo acadêmico, tendo inclusive participado do movimento estudantil grevista; e Maurício (o mais novo) se formou em um ambiente acadêmico mais favorável às novas doutrinas.

42. Cf. Nascimento e Botas (2014).

43. A pesquisa coordenada pelo professor Nabil Bonduki levantou cerca de trezentos conjuntos residenciais entre os anos de 1995 e 2010 .

44. Cf. Bonduki e Koury (2014).

45. Regino e Perrone (2009, p. 77). 
46. Cf. Kneese de Mello ([19--?]).

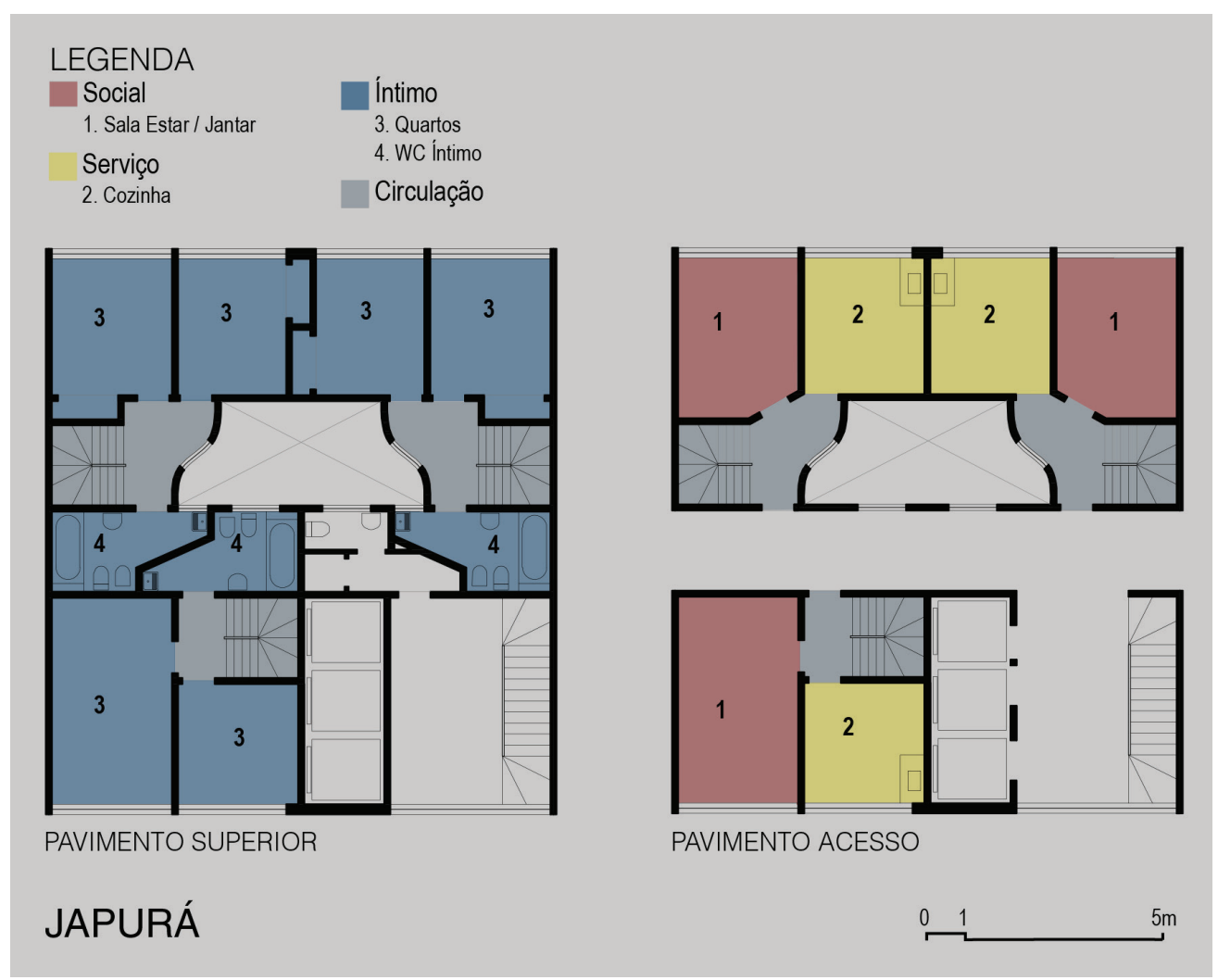

Figura 11 - Plantas do Japurá. Desenho: Gabriela Piccinini e Sabrina Costa (2018)

Kneese de Mello defendeu a escolha da tipologia duplex em uma publicação que apresentou seu projeto. $\bigcirc$ arquiteto listou entre suas vantagens questões de ordem econômica (não havendo corredor comum nos andares destinados a dormitórios, o número de paradas dos elevadores fica reduzido à metade, tornando-os mais econômicos e eficientes, além da economia de volume de pé-direito) no gabarito determinado pelo Código de Obras, e a reunião das áreas molhadas garantia que o mesmo poço de iluminação e ventilação sirva a quatro banheiros por andar. Além disso, o arquiteto destaca a importância de separar áreas íntimas daquelas que precisam de contato com o exterior (sala e cozinha), garantindo a privacidade dos dormitórios. ${ }^{46}$

Os desenhos do arquiteto explicitam como as áreas comuns e os apartamentos podem ser utilizados. Nos apartamentos, são demonstrados como pequenos espaços devem ser ocupados: armário embaixo da escada, tanque de lavar roupa no banheiro, máquina de costura no hall de acesso aos quartos. As imagens descritas revelam a intenção do arquiteto em promover sua concepção sobre o modo de morar moderno. 
Os Institutos de Aposentadoria e Pensões buscavam produzir moradias econômicas e acessíveis para seus associados, mas o equilíbrio econômico financeiro da intervenção e o retorno dos investimentos eram aspectos importantes a serem considerados. Nesse sentido, a construção do edifício Japurá representou para o lapi a busca de um investimento seguro para os fundos previdenciários. ${ }^{47}$

No condomínio, os personagens são representados desempenhando várias atividades. No subsolo, duas figuras femininas aguardam sentadas um garçom que se aproxima da mesa do restaurante, crianças brincam na área de recreação enquanto duas mulheres observam-nas; nas áreas destinadas ao comércio do bloco horizontal, uma mulher está sentada em uma cadeira enquanto outras duas mulheres cuidam de suas unhas e cabelos, indicando a possibilidade de aquele espaço abrigar um salão de beleza, enquanto uma mulher em frente a um balcão aguarda um homem entregar-the algo. Neste caso, não fica muito claro se o espaço seria um bar, uma lanchonete ou uma mercearia. No terraço, uma mulher em pé observa o horizonte, enquanto outra toma sol deitada em uma espreguiçadeira. $\bigcirc$ projeto do paisagismo desenvolvido por Burle Marx para o edifício demostrava a importância almejada das áreas comuns para os usuários do conjunto.

$\bigcirc$ arquiteto Kneese de Mello ainda viria a utilizar a tipologia dos duplex em outros empreendimentos na cidade de São Paulo. Antes mesmo da construção do Japurá, em 1944, ele propôs o Conjunto Residencial Cidade Jardim para o Instituto de Aposentadorias e Pensões dos Comerciários (IAPC). $\bigcirc$ complexo não foi construído, mas já demonstrava o vínculo de Kneese de Mello aos preceitos da arquitetura moderna, a ideia de redução dos espaços domésticos e o apoio de equipamentos coletivos.

Este projeto procurou solucionar o problema da habitação por intermédio da implantação de 1118 unidades residenciais, sendo 520 apartamentos com um dormitório, 80 apartamentos duplex com dois dormitórios, 486 casas com três dormitórios e 32 casas com quatro dormitórios; e seus prolongamentos contendo escola, centro comercial, maternidade, ambulatório, oficinas para pequenos serviços, playground e centro esportivo. ${ }^{48}$

Além deste, afastado da região central da cidade, foi projetado o Conjunto Residencial Ana Rosa (1950), empreendimento do Banco Hipotecário Lar Brasileiro, num grande terreno acidentado localizado na Vila Mariana. A primeira versão do projeto compreendia um edifício de uso misto (residencial e comercial), com residências isoladas e casas geminadas. ${ }^{49}$ A proposta construída conta com seis blocos de três andares, com catorze apartamentos por pavimento em média (Figuras 12 e 131.
47. Bonduki, Silva e Koury (2014, p. 147).

48. Regino e Perrone (2009, p. 75).

49. Regino e Perrone (2009, p. 85). 


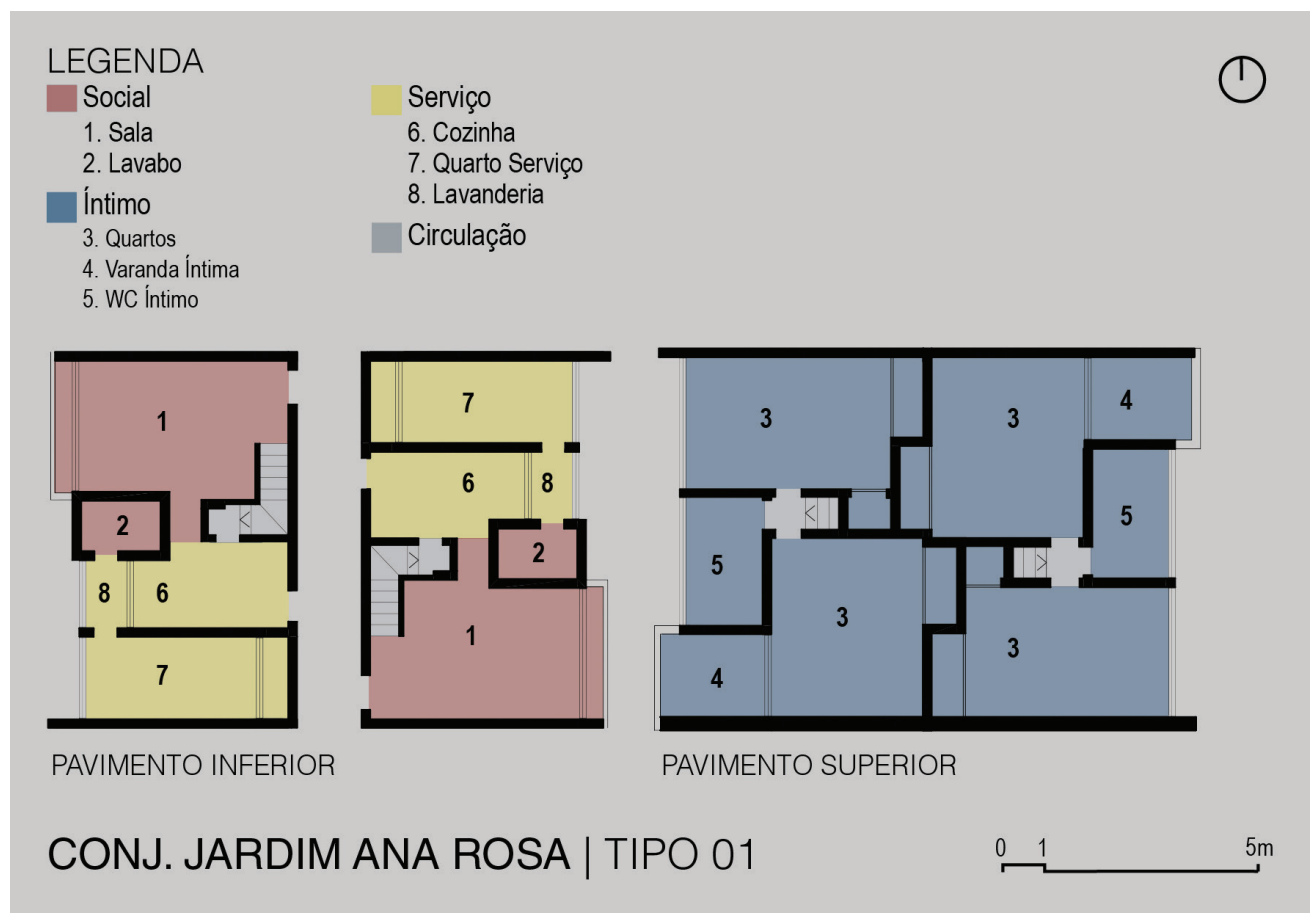

Figura 12 - Planta do apartamento Tipo 1 do Conjunto da Ana Rosa. Desenho: Gabriela Piccinini e Sabrina Costa (2018)

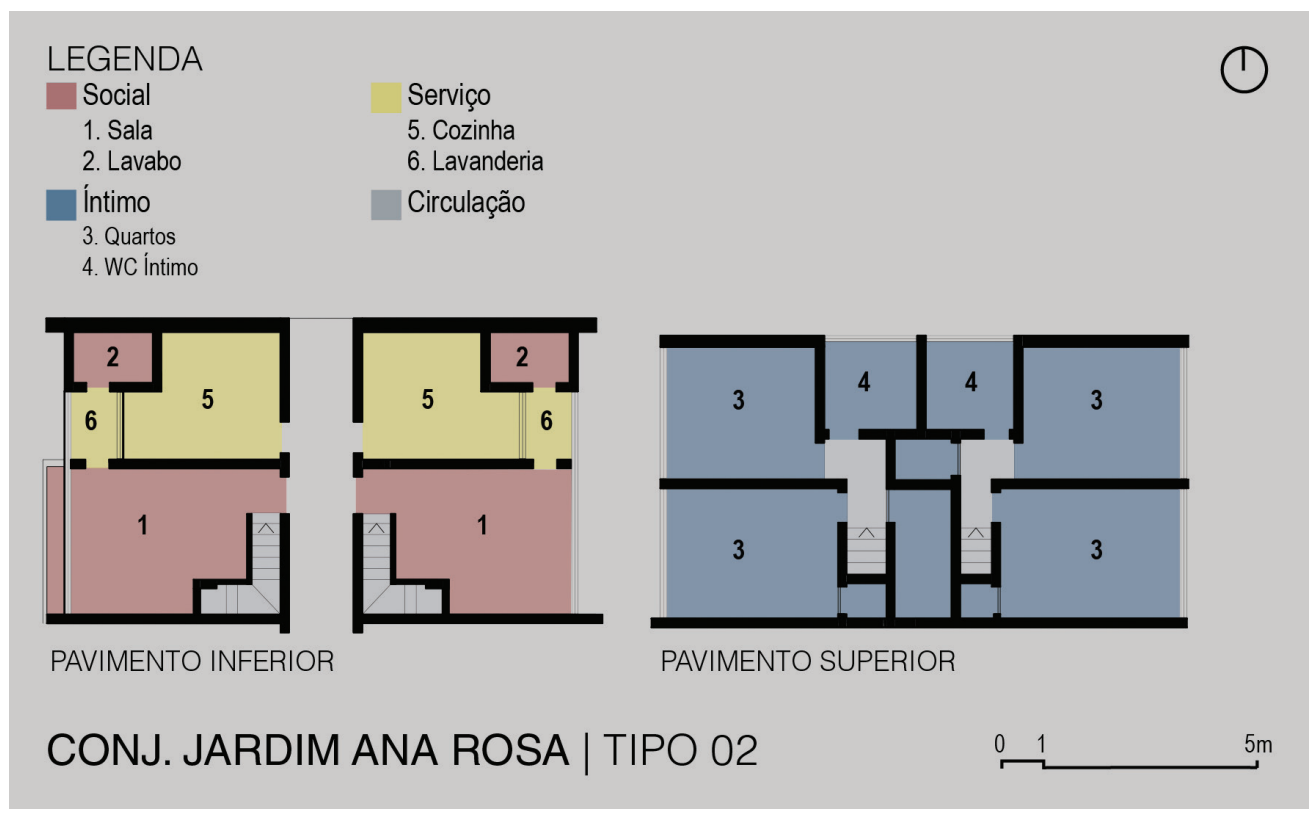

Figura 13 - Planta do apartamento Tipo 2 do Conjunto da Ana Rosa. Desenho: Gabriela Piccinini e Sabrina Costa (2018) 
Buscando a economia na construção, racionalização e redução dos corredores de acesso aos apartamentos, o arquiteto se utiliza do grande desnível do terreno para realizar os acessos. A partir do ponto mais alto - a Rua Dr. José de Queiroz Aranha - as passarelas realizam a ligação do espaço público com o arquitetônico, que se dividem nos três andares de acesso a partir de escadas e rampas. Os amplos jardins permeiam as ligações e tornam os acessos externos mais interessantes. No entanto, os corredores internos que dão acesso aos apartamentos são únicos, forçando os moradores dos imóveis da ponta a realizar longos deslocamentos. ${ }^{50}$

Neste projeto, por dispor de áreas maiores, a lavanderia está presente, assim como o quarto e sanitário de serviços (dispostos no pavimento inferior, juntamente com a sala). No pavimento superior, além dos dois dormitórios e de um banheiro, existe um grande caixilho com jardineira, de onde é possível apreciar os belos jardins entre os blocos.

Um projeto de impacto no que se refere aos conjuntos habitacionais de caráter social é o Conjunto Residencial Prefeito Mendes de Morais, conhecido como Pedregulho. $O$ empreendimento é considerado por muitos críticos de arquitetura juntamente com o Museu de Arte Moderna do Rio de Janeiro - como obra-prima do arquiteto Affonso Eduardo Reidy, e o principal empreendimento promovido pelo Departamento de Habitação Popular (DHP), sob a direção de Carmem Portinho.

A primeira etapa do projeto foi inaugurada em 1950 e constava de dois blocos residenciais retos (Bloco B) de quatro andares, formado por 56 unidades habitacionais, apartamentos duplex de dois, três ou quatro quartos, além de mercado, lavanderia e centro de saúde para atender as demandas dos moradores, formando uma "unidade de vizinhança", ideia tão defendida por Carmem Portinho - tudo isto cercado por um jardim projetado por Burle Marx. Os outros equipamentos - escola, piscina, vestiário e ginásio de esportes - foram inaugurados em 1951.

Projetado para ter 533 unidades e uma gama completa de equipamentos e serviços coletivos, o Pedregulho seria destinado para funcionários de baixos salários da prefeitura. Integra-se à proposta de habitação social para a cidade do Rio de Janeiro elaborada pelos técnicos do Departamento de Habitação Popular da prefeitura, cujo pressuposto era combater os crescentes e alarmantes problemas da moradia da capital federal, onde favelas e moradias precárias cresciam nas estatísticas e nas notícias da imprensa diária. ${ }^{51}$

Reconhecido na historiografia da arquitetura por sua proposta arrojada e escala monumental, o grande conjunto curvo (Bloco A) abriga 272 apartamentos variando de 26 a $78 \mathrm{~m}^{2}$ e foi parcialmente inaugurado em 1958, mas sua ocupação total se deu em 1960. Seu terceiro piso é tratado como área de
51. Nascimento (2017, p. 374-375). 
52. Nascimento (2017).

53. Nascimento (2017, p. 389). circulação e convivência comunitária, onde atividades das mais variadas podem ocorrer (administração, comércio, espaços educativos, entre outros). Neste nível há - acesso da Rua Marechal Jardim para o edifício, por meio de duas pontes de ligação. De lá é possível ter uma vista geral da cidade, ter consciência da dimensão do conjunto e de seu impacto na paisagem.

Neste terceiro pavimento se dá o acesso aos apartamentos, distribuídos por quatro caixas de escadas alocadas ao longo do extenso bloco. Descendo para os segundo e primeiro andares acessam-se as unidades menores, voltadas para os casais sem filhos (com cozinha, banheiro, sala e um quarto). Nos quatro pavimentos superiores distribuem-se os apartamentos duplex, com dois ou três dormitórios, cujo acesso é realizado pelo quarto e sexło andares (Figura 14). Essa distribuição libera o conjunto do uso de elevadores.

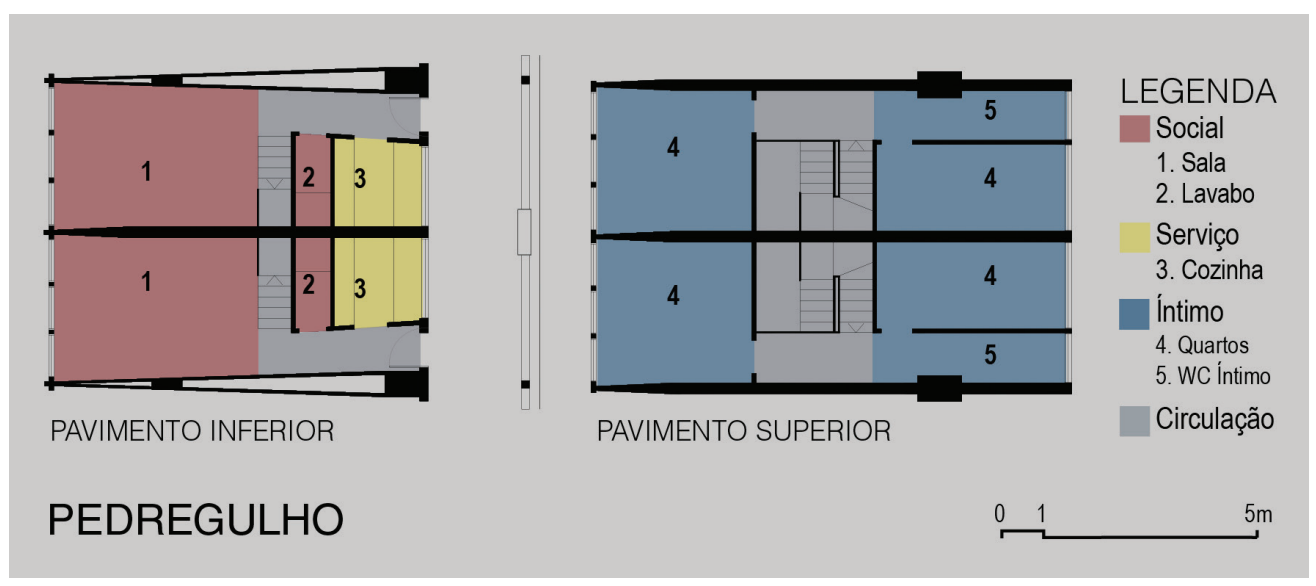

Figura 14 - Planta dos apartamentos duplex do Bloco A do Pedregulho. Desenho: Gabriela Piccinini e Sabrina Costa (2018)

Os dois blocos do Tipo B (B 1 e B2) são edifícios de quatro andares sobre pilotis com apartamentos duplex. Aqui encontram-se os maiores apartamentos do conjunto, com sala, cozinha e varanda no térreo, e quatro quartos e banheiros no andar superior. Assim como no Bloco A, os corredores de acesso são fechados por painéis de cobogós.

Como bem demonstrou Flavia Nascimento, Carmem se preocupava com o uso correto das moradias. ${ }^{52}$ Para tanto, as assistentes sociais do DHP deveriam assessorar o uso dos apartamentos e dos espaços comuns. Além disso, um dos apartamentos do Bloco B foi "destinado ao serviço social do conjunto, mobiliado de maneira 'moderna e econômica', servindo de exemplo para os moradores". ${ }^{53}$ 
A escolha da tipologia duplex nos dois blocos certamente se relaciona às pesquisas de Carmem Portinho, na época em que esteve na Inglaterra com uma bolsa de estudos do governo britânico, sobre o programa de reconstrução das cidades destruídas pela guerra. Desta maneira, as habitações têm suas áreas reduzidas para diminuir os custos e também para incentivar o uso de seus equipamentos coletivos, que colaborariam com uma maior liberdade com relação às atividades domésticas. Ou como afirmou Silvana Rubino, "é dessa pioneira do feminismo no Brasil a interferência que fez com que o conjunto tivesse uma lavanderia coletiva, para resguardar o trabalho feminino de uma dupla jornada". ${ }^{54}$

\section{A VOLTA DA MORADA BURGUESA E DOS PADRÕES TRADICIONAIS}

A tipologia duplex surgiu como uma alternativa para a habitação de massa com áreas mínimas. No entanto, ainda nas primeiras décadas do século XX, algumas experiências já mostravam que esta tipologia poderia ser explorada comercialmente por famílias mais abastadas interessadas em apartamentos amplos. Em 1935, o arquiteto russo Berthold Lubetkin projetou o conjunto Highpoint II, com doze apartamentos duplex num local privilegiado de Londres. Com duas possibilidades de plantas e áreas bem generosas (Figuras 15 e 16), a construção deste edifício demonstrava que a proposta dos arquitetos russos poderia ser aplicada para contextos socioeconômicos diversos, como será apresentado neste item.

No Brasil, alguns empreendimentos que se utilizavam de amplos apartamentos duplex interessaram às famílias de maior poder aquisitivo, a exemplo do Julio Barros Barreto. No entanto, é possível observar a apropriação e alteração do modelo já nas primeiras experiências paulistanas.

O primeiro edifício moderno com a tipologia duplex em São Paulo foi o multifuncional Esther (1937). Símbolo da modernidade paulistana, o conjunto localizado na avenida Ipiranga abrigava originalmente lojas comerciais no pavimento térreo, salas de escritório e consultórios médicos e odontológicos, apartamentos simples e os inovadores duplex espalhados ao longo de seus onze pavimentos.

A iniciativa foi realizada pela família Nogueira, dona da Usina Esther, no interior de São Paulo. ${ }^{55}$ Buscava-se diversificar seus investimentos e empreender em uma região que se transformava intensamente com a substituição das antigas chácaras e casarões pelos edifícios com mais de quatro andares. ${ }^{56}$ Por meio de um concurso de ideias, foi selecionado o projeto dos arquitetos cariocas Álvaro 


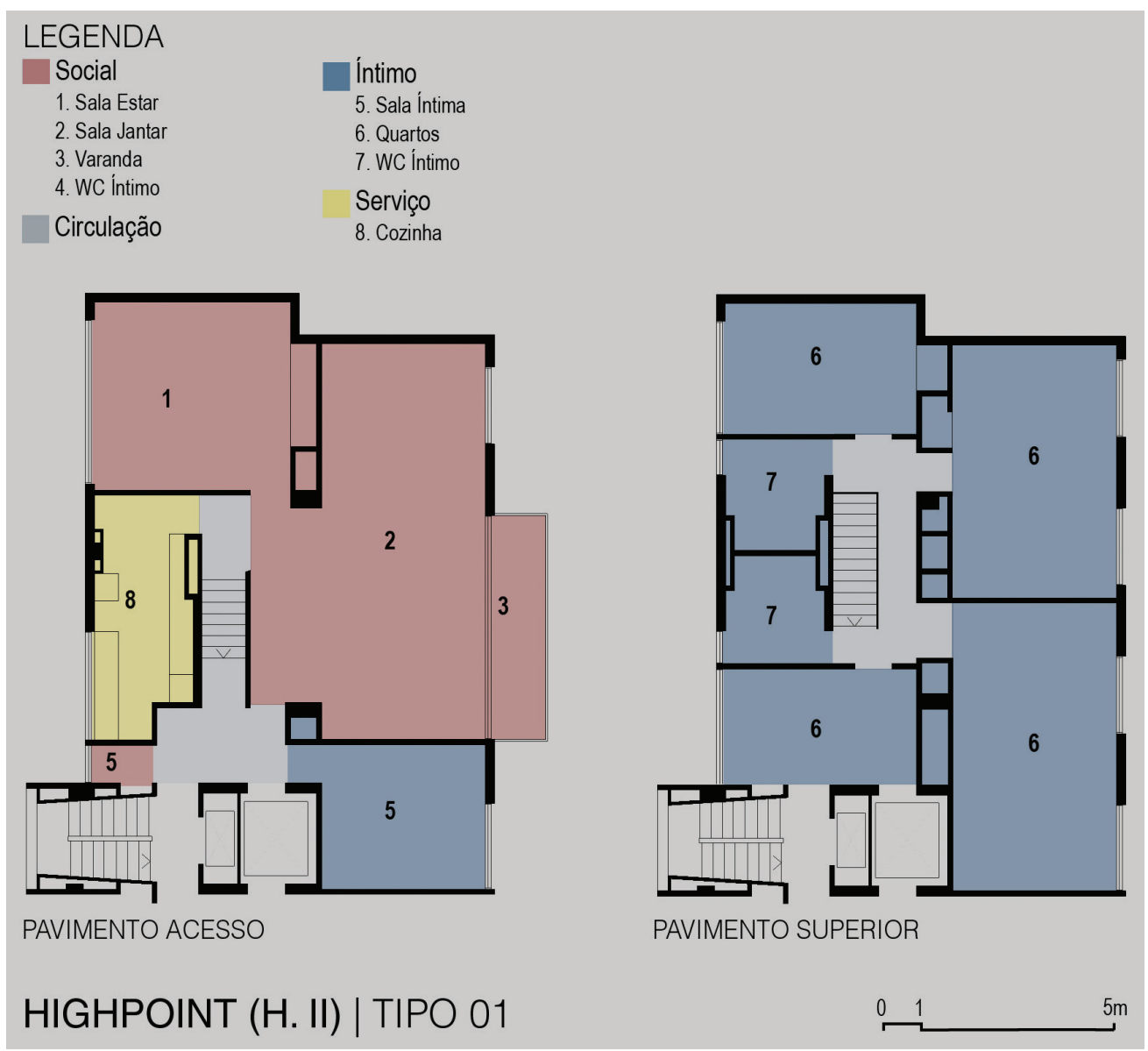

Figura 15 - Planta do Tipo 1 do Highpoint II. Desenho: Gabriela Piccinini e Sabrina Costa (2018)

Vital Brazil e Adhemar Marinho pela viabilidade financeira da proposta, que trazia ainda os elementos vinculados à proposta corbusiana: planta livre, espaços flexíveis e janelas corridas nos andares de escritório, diferentes recursos de proteção à insolação nas diversas fachadas. Além disso, são reconhecíveis os atributos relacionados à arquitetura moderna nos acabamentos utilizados e na flexibilidade de usos possíveis em seus andares.

Com relação aos espaços de morada, a diversidade de opções de plantas permite que moradores com perfis diversos habitem o edifício: desde quitinetes aos amplos apartamentos duplex (denominados por Vital Brazil como "apartamentos duplos de luxo"). $\bigcirc$ prédio foi ricamente registrado para a exposição (que se tornaria livro) "Brazil builds" na década de 1940, quando foi descrito como o melhor exemplar da vida moderna ${ }^{57}$ As fotos da exposição e do livro mostram os apartamentos vazios, sem mobiliários ou usuários. 


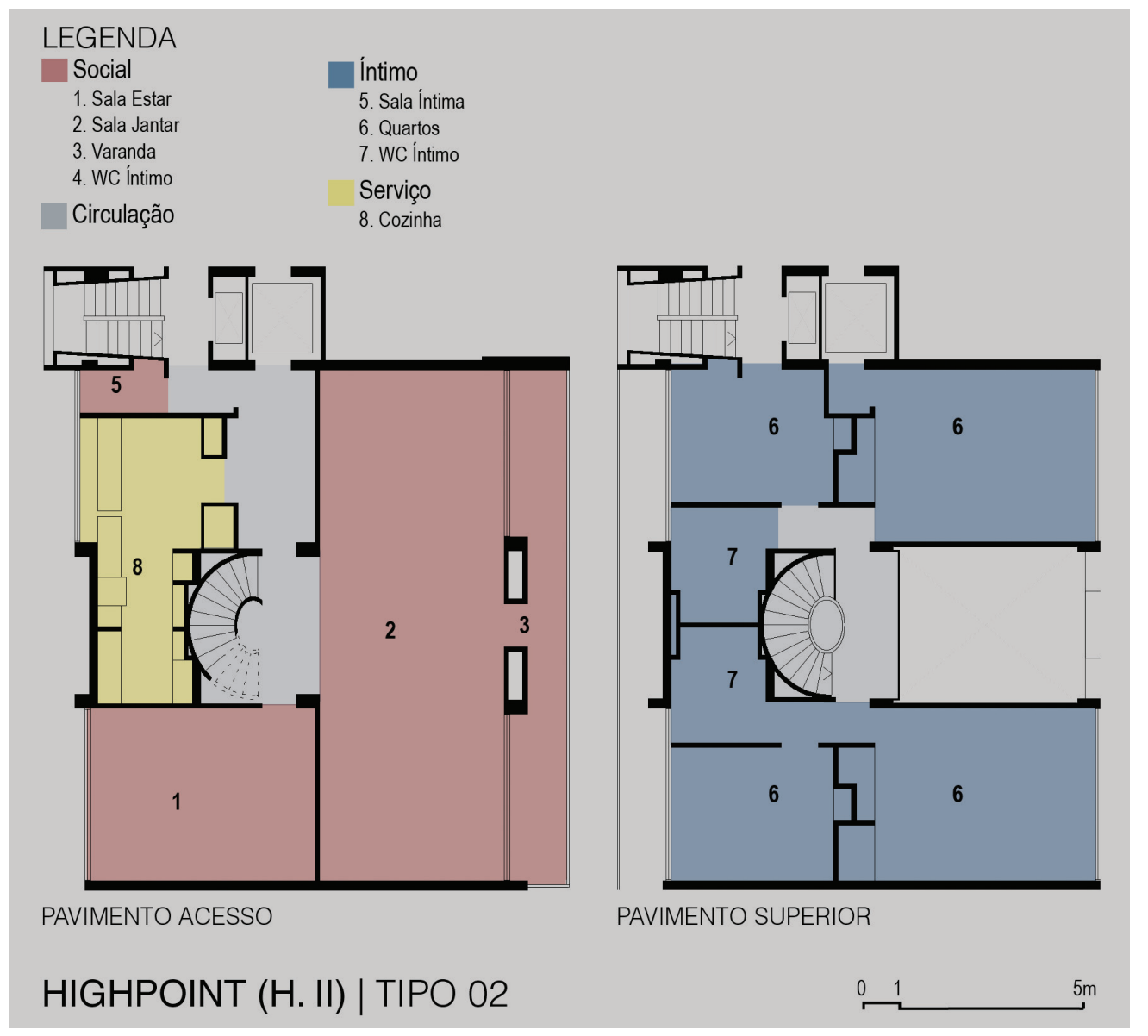

Figura 16 - Planta do Tipo 2 do Highpoint II. Desenho: Gabriela Piccinini e Sabrina Costa (2018)

Os apartamentos duplex organizavam suas áreas íntimas, sociais e de serviços em dois pavimentos. No inferior encontram-se uma sala de estar com pé direito duplo, vestíbulo, escada, sala de jantar, cozinha, dispensa e dependências de empregados, enquanto no superior estão três dormitórios, um banheiro e um lavabo (Figura 17). Os acessos ao apartamento são muitos, dois em cada andar. Neste caso, a economia de parada de elevadores defendida pelo arquiteto Eduardo Kneese de Mello não ocorre. Tanto o nono quanto o décimo andar apresentam corredores e acessos próprios.

Analisando a planta é perceptível que os espaços sociais são amplos e voltam-se para o exterior, enquanto os de serviço são mais exíguos (inclusive o quarto de empregada), voltados para o fosso interno do edifício. No pavimento superior, é interessante observar a presença de um banheiro e um lavabo que atendem aos moradores, características que atestam sua condição financeira mais favorável. 

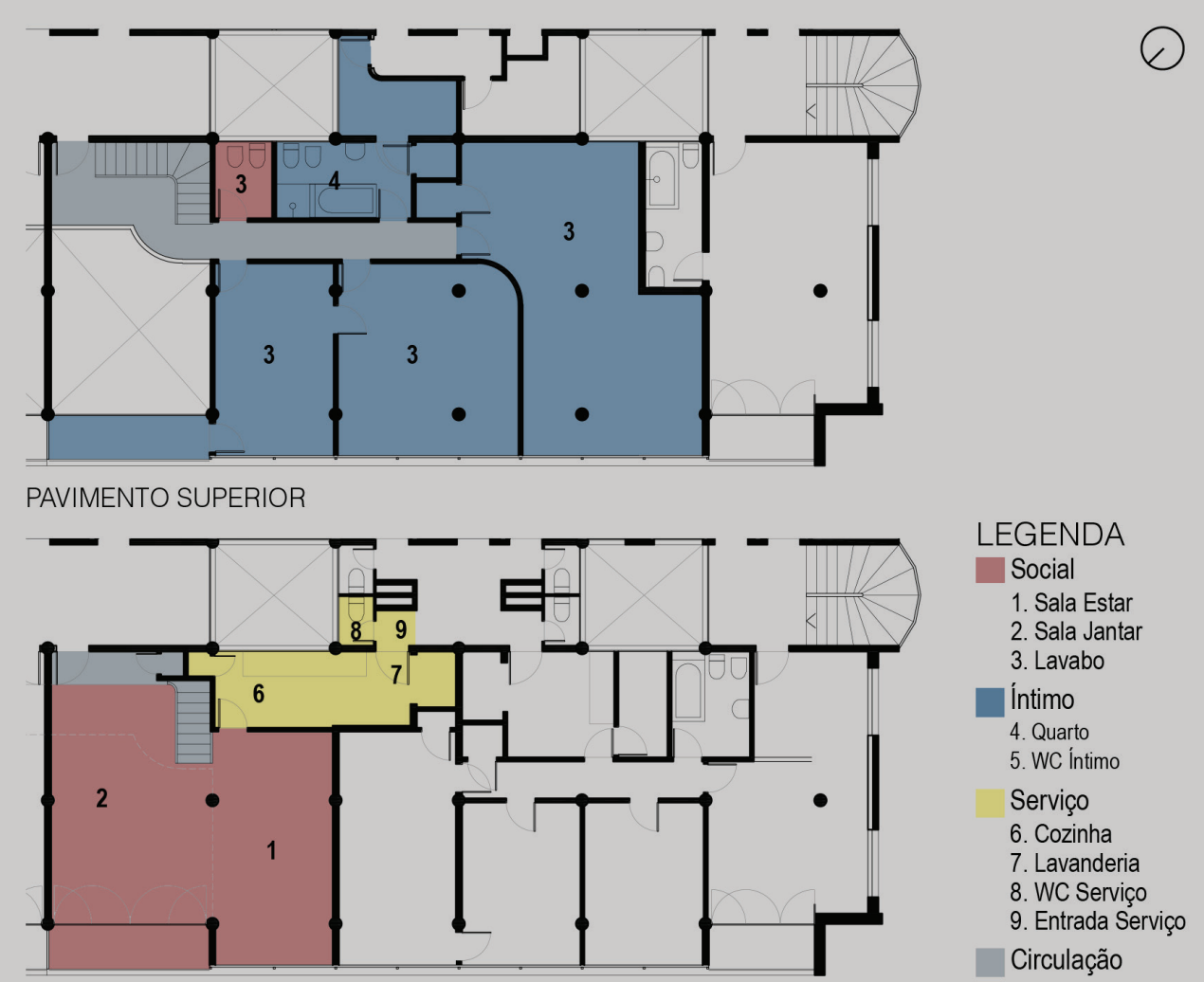

PAVIMENTO INFERIOR

\section{EDIFÍCIO ESTHER}

Figura 17 - Planta do apartamento duplex do Esther. Desenho: Gabriela Piccinini e Sabrina Costa (2018)

Outro aspecto que reforça esta ideia é a localização do edifício, no entorno da Praça da República, de frente a um dos principais eixos de circulação e investimentos governamentais do período de construção, a Avenida lpiranga. De fato, morar tendo a vista dessa praça - um dos oásis verdes do Centro - era um privilégio de poucos. Ou, como afirmou Pierre Bourdieu, ${ }^{58}$ as maneiras de habitar e os lugares de suas habitações revelam posições sociais. Nas proximidades do Esther, menos de duas décadas após sua inauguração, seria construído o edifício Eiffel.

anúncio do jornal Folha da Manhã de 23 de março de 1952 apresenta o empreendimento:

Situação: basta dizer que é na Praça da República, no seu melhor ângulo residencial, repleto de beleza verde das folhagens, com 58 metros de frente para a tradicional praça de São Paulo. Confôrto: tudo previsto, minuciosos detalhes apreciados, no sentido de proporcionar o mais alto conforto. 
No trecho anterior, a noção de conforto aqui está associada ao controle dos aspectos espaciais e construtivos da edificação. A pesquisadora francesa Monique Eleb afirma que "ao longo do século XX, a noção de conforto passou da expressão de um sentimento qualitativo e subjetivo para uma noção mensurável e objetiva, relativa à ideia de equiparar a habitação e ligado ao progresso". 59 Neste sentido, o texto do anúncio deixava claro que a habitação estava adequada às demandas por água encanada, luz, telefone e outras redes técnicas necessárias para garantir um cotidiano saudável nos moradores daquele empreendimento. Além disso, vale a pena retomar a explicação do professor e arquiteto Carlos Lemos para essa questão: "oferecia-se o máximo de conforto porque exigia-se distinção completa entre prédios de apartamentos e cortiços ou casas de cômodos" .60

Conforme anunciado, o prédio da Companhia Nacional de Investimentos foi projetado por Oscar Niemeyer, com a colaboração de Lemos entre $1951 \mathrm{e}$ 1955. Daniela Lealol defende que a contratação de arquitetos vinculados à vertente moderna da área nos empreendimentos imobiliários, a partir de meados da década de 1940, se relaciona com a imagem do progresso transmitida pelas construções.

O edifício de apartamentos, neste momento, veiculava a imagem de progresso e avanço técnico, gerando uma rentabilidade bem superior à das habitações horizontais de aluguel construídas até então, inclusive por permitir a sobreposição de unidades em uma mesma gleba, em vários pisos. ${ }^{62}$

Neste mesmo período que Oscar Niemeyer projetava o Eiffel, os edifícios Copan e Montreal estavam sendo desenhados como habitação de diversos formatos e tipologias para os habitantes da metrópole que se consolidava.

Sua torre reúne cinquenta e quatro apartamentos duplex de variados tamanhos, enquanto o térreo abriga uma galeria comercial. ${ }^{63} \bigcirc$ acesso aos apartamentos se dá pelo pavimento superior, onde se localizam a sala, cozinha e área de serviço, enquanto no inferior ficam os dormitórios e banheiros. Segundo Lemos, $^{64}$ a inversão (áreas sociais acima, áreas íntimas embaixo) é uma tentativa de isolar os sons de cada família em seu próprio domínio. Assim, os barulhos dos eventos sociais produzidos na sala incomodariam apenas os moradores do mesmo apartamento que estivessem em seus dormitórios, o que parece atestar uma intensa vida social.

Os apartamentos se dividem basicamente em dois tipos: aqueles que ficam no corpo central do edifício (Tipo 1) são menores e contam com sala, cozinha e uma pequena área de serviço no pavimento superior e dois dormitórios e um banheiro no inferior; enquanto os localizados nos braços do edifício (Tipo 2) contam
59. Eleb (2011).

60. Lemos (1976, p. 162).

61. Leal (2003).

62. Villa (2002, p. 84).

63. Costa (2015)

64. Entrevista com o professor Carlos Lemos realizada na FAU-Maranhão no dia 19 de janeiro de 2016. 
com quatro dormitórios e dois banheiros no pavimento inferior, e uma sala, ampla cozinha e área de serviço no superior (Figuras 18 e 19). Nos dois tipos, um quarto de empregada comprova a presença de funcionários no cotidiano das famílias.

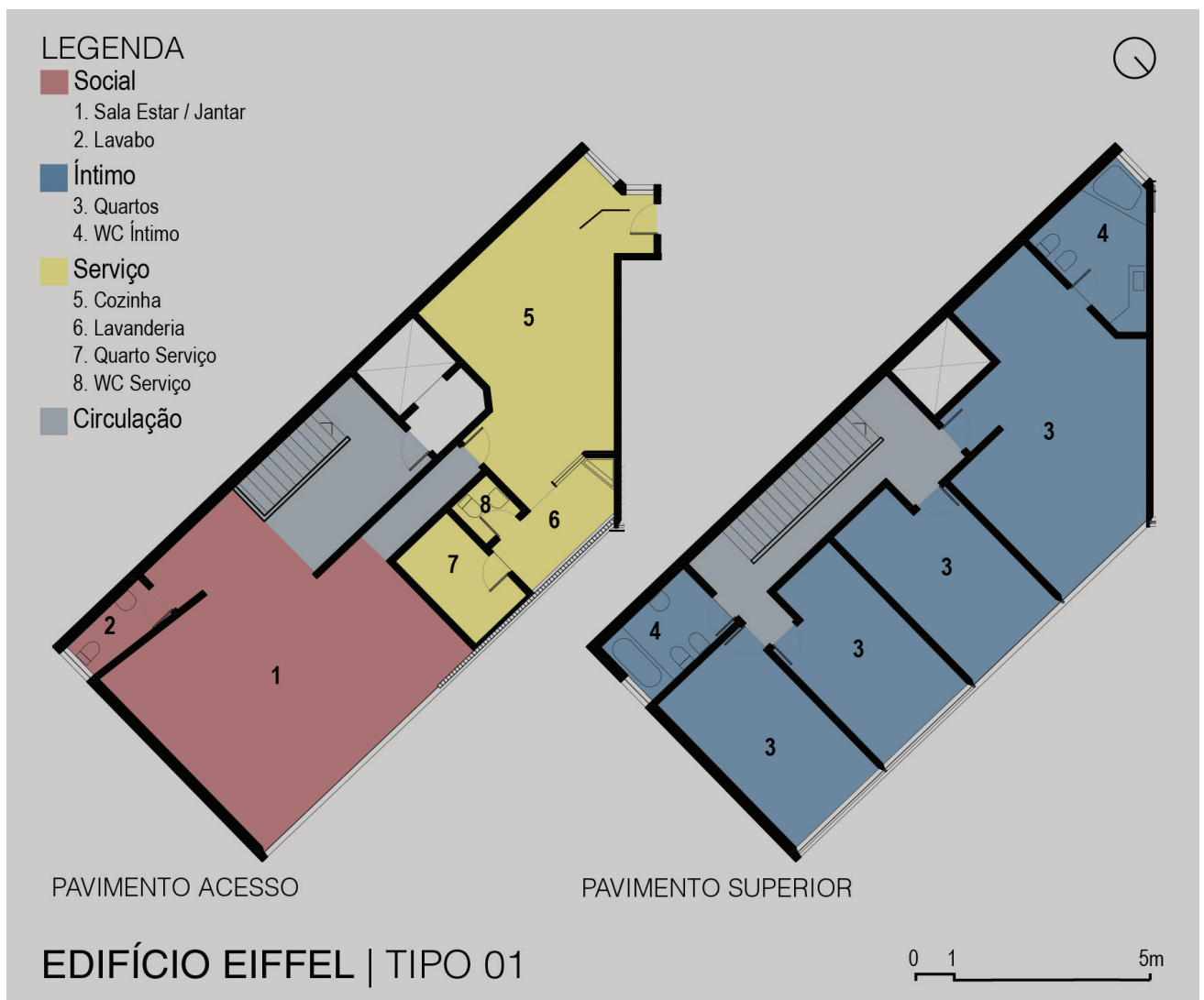

Figura 18 - Planta do apartamento Tipo 1 do Eiffel. Desenho: Gabriela Piccinini e Sabrina Costa (2018)

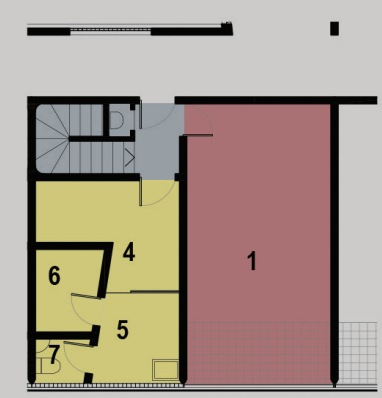

PAVIMENTO ACESSO

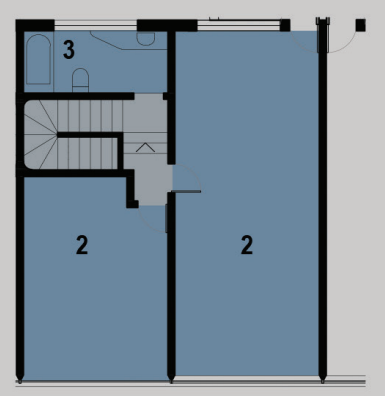

PAVIMENTO SUPERIOR

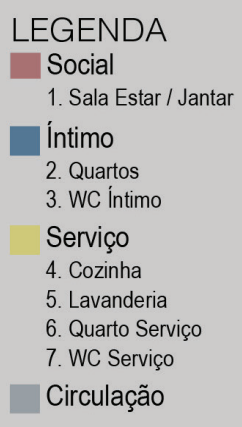

$0 \quad 1$ $5 \mathrm{~m}$

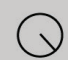

EDIFÍCIO EIFFEL | TIPO 02

Figura 19 - Planta do apartamento Tipo 2 do Eiffel. Desenho: Gabriela Piccinini e Sabrina Costa (2018) 
Outro conjunto com apartamentos duplex que se destaca pelas dimensões e pela organização espacial foi idealizado por Lúcio Costa no Rio de Janeiro, o Parque Guinle (Figura 20). Construídos em Laranjeiras, os edifícios Nova Cintra, Bristol e Caledônia faziam parte de um conjunto original de seis blocos. Eles estão implantados num amplo parque, elevados sobre pilotis e rodeados pelos jardins de Burle Marx, que faz a transição entre a paisagem natural e as construções. Costa explica a intenção de seu projeto aos empreendedores quando consultado:

Aconselhei então uma arquitetura contemporânea que se adaptasse mais ao parque do que a mansão, e que os prédios alongados, de seis andares, fossem soltos do chão e dispusessem de "loggias" em toda a extensão das fachadas, com vários tipos de quebra-sol, já que davam para o poente. Foi o primeiro conjunto de prédios construídos sobre pilotis e o prenúncio das superquadras de Brasília. ${ }^{65}$

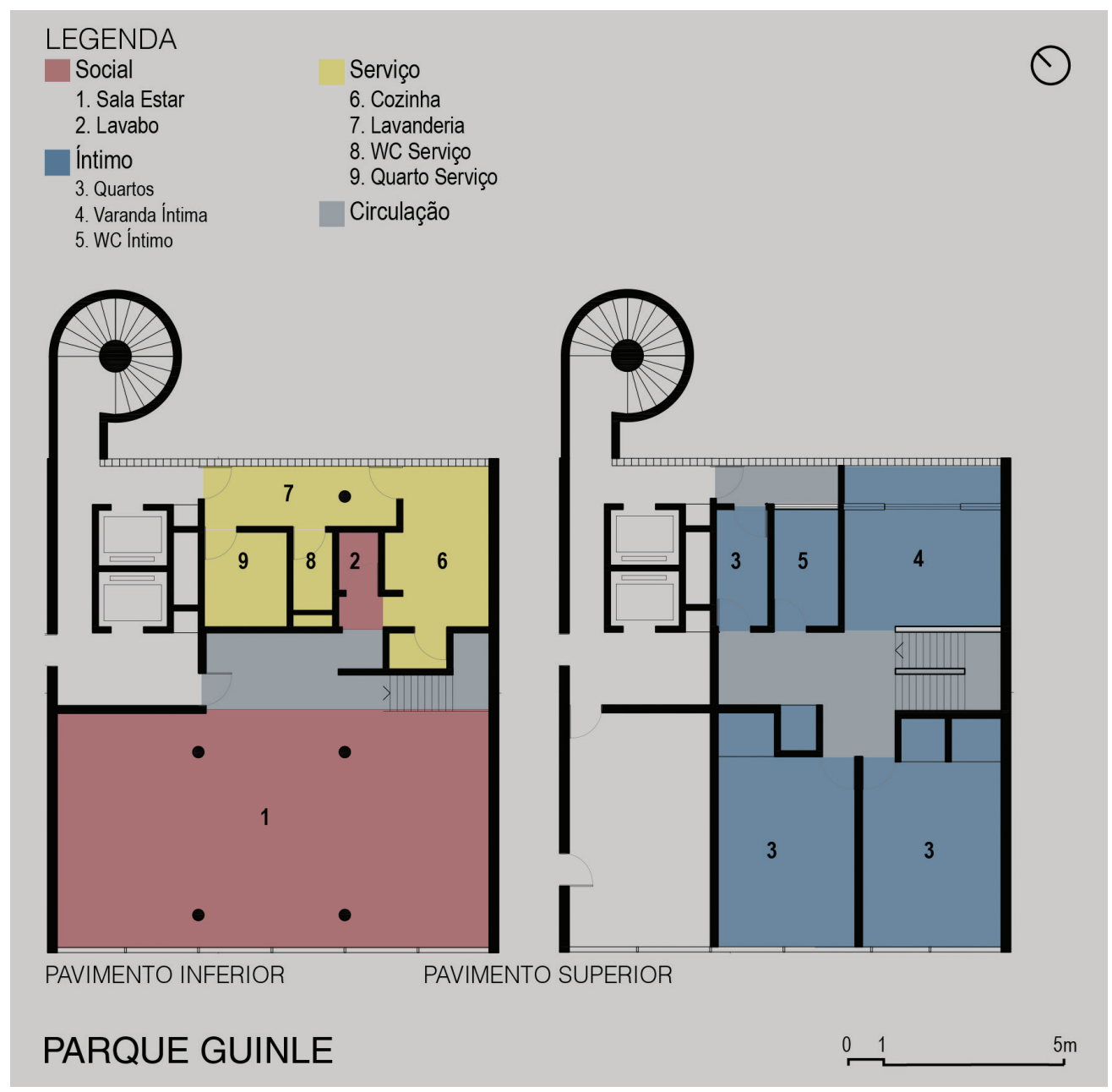

Figura 20 - Apartamento duplex no conjunto do Parque Guinle. Desenho: Gabriela Piccinini e Sabrina Costa (2018) 
66. Coelho (2006).

67. Marins (1998, p. 187).

68. Costa (1995, p. 212).

69. Lemos (1976).

70. Lemos (1976, p. 162).

71. Marins (1998, p. 192).

72. Villa (2002)
As plantas dos apartamentos variam entre 286 a 604 m²$^{2}$, com quatro tipos, sendo seis duplex por edifício. Nos três edifícios, a parte central do segundo ao sétimo pavimentos é ocupada por apartamentos duplex de dois dormitórios. ${ }^{66}$ No que se refere à organização espacial desses apartamentos de dois andares, em geral o pavimento inferior é dotado de uma grande sala que se separa das áreas de serviço (cozinha, lavanderia, quarto e banheiro de serviço) pela escada, que dá acesso ao piso superior, onde se encontram três dormitórios, um banheiro e uma varanda íntima.

Os apartamentos são previstos para famílias abastadas que se propõem a morar em conjuntos multifamiliares, sob a condição de terem garantidos os espaços da vida tradicional. Como nos dois outros prédios analisados anteriormente, no conjunto do Parque Guinle também as grandes áreas, sua distribuição e os materiais garantiam a imagem de sofisticação dos empreendimentos. "O receio de decair socialmente, advindo do desprezo com as coabitações, foi vencido com a adoção de acabamentos custosos utilizados nos revestimentos externos e nas áreas internas de circulação dos edifícios". ${ }^{67}$ Costa ainda afirma que esta seria a "primeira experiência de um conjunto residencial de apartamentos destinados à alta burguesia". 68

A presença dos espaços para os empregados nesses apartamentos modernos se relaciona com a ideia de Lemos, ao afirmar que se buscava ao máximo aparentar uma vida luxuosa e recatada entre as famílias de classes média e altas. ${ }^{69}$

Os edifícios deveriam ter "entradas nobres" e entradas de serviço. $\bigcirc$ acesso à rua poderia ser uma só, mas dentro, logo no térreo, as circulações passariam a ser diferenciadas. Deveriam ter cozinha, tanque, banheiro e quarto da criada, pois toda família que se prezava tinha uma empregada morando em casa. Deveriam ter duas salas, inclusive a de visitas. E quarto dos bons. $\bigcirc$ acabamento, o melhor possível. ${ }^{70}$

Para ser entendido como um lar "de respeito", sua organização espacial deveria manter os empregados isolados na casa, nas dependências de serviço.

A diferenciação rígida entre áreas íntimas e de serviço - e entre seus respectivos ocupantes - foi um anseio que escapou largamente aos apartamentos de luxo. A permanência e a circulação mereceram a criação de caminhos e espaços diferenciados, sedimentando para os setores médios uma distinção em que se sente o bafejar dos tempos de escravidão. ${ }^{71}$

Simone Villa aborda como as áreas dos quartos de empregada diminuem ao longo das décadas, mas se mantendo mal ventiladas e iluminadas, escondidas e isoladas. ${ }^{72}$ 


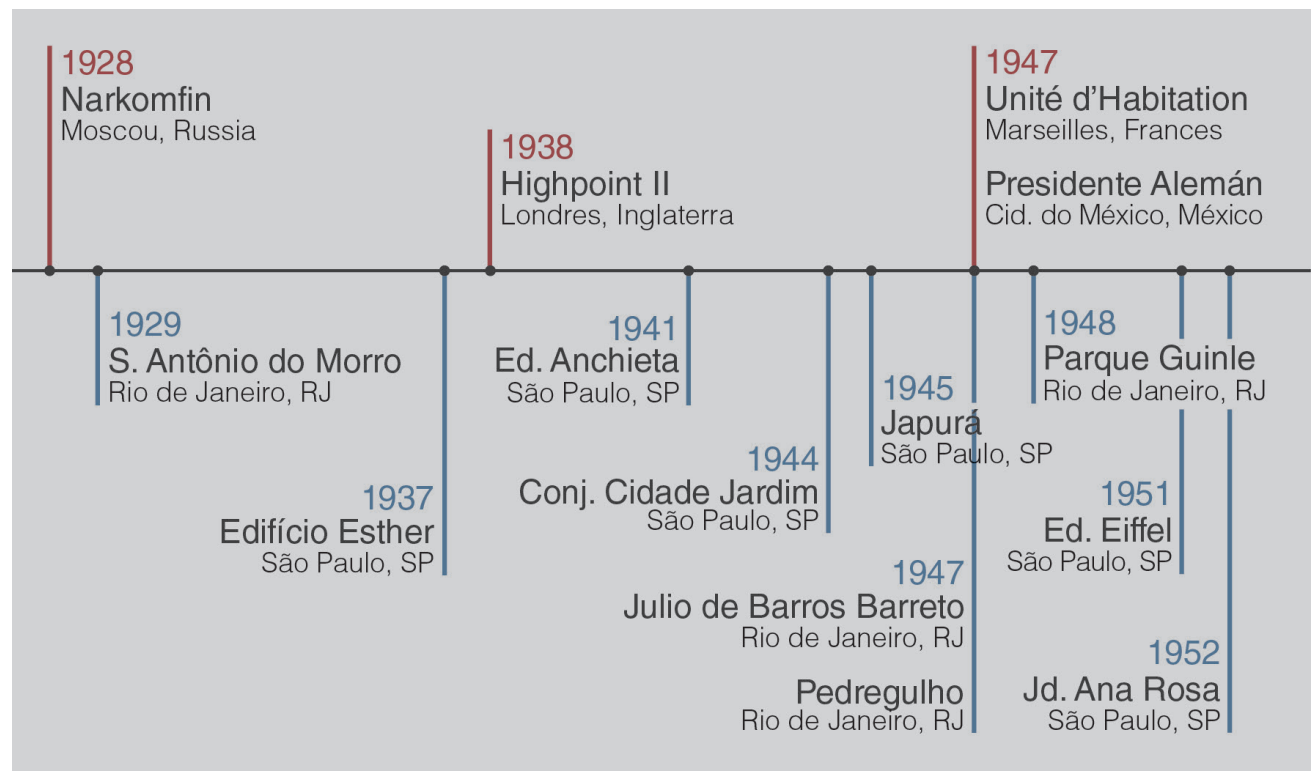

Figura 21 - Breve linha do tempo dos conjuntos com apartamentos duplex. Desenho: Gabriela Piccinini e Sabrina Costa (2018)

\section{CONSIDERAÇÕES FINAIS}

A busca por novos modos de morar foi uma ambição entre os arquitetos modernos. Nas propostas de casas, apartamentos e conjuntos habitacionais que marcam a primeira metade do século XX, é perceptível a crença de que a partir de novos arranjos espaciais seria possível desenvolver novos hábitos e rotinas que garantiriam uma vida mais saudável e equilibrada para seus moradores. Neste contexto, o discurso de ter uma arquitetura voltada para um modo de vida moderno ${ }^{73}$ era difundido com frequência, sugerindo que as novas construções propiciariam o uso do tempo de maneira mais produtiva e eficiente, consequentemente possibilitando mais momentos de lazer e cuidados com o corpo - preocupações que estão na agenda dos profissionais que pensaram nos impactos da Revolução Industrial sobre as cidades do século XIX. Não se tratava apenas de construir habitações para os novos operários, para os que perderam suas casas nas guerras ou para a leva de imigrantes que chegava às metrópoles, mas sim fornecer habitações de qualidade, que incentivassem os trabalhadores a vivenciar novas práticas domésticas.
73. Na passagem do século XIX para o século XX, o termo "moderno" foi frequentemente associado à ideia do novo, do progresso, da liberdade e da emancipação. Segundo o historiador Nicolau Sevcenko (2003), este vocábulo se intensifica a partir de três amplos contextos: a revolução tecnológica, a passagem do século e o pós-guerra. 
74. A expressão "mulher moderna" - utilizada e reforçada em manifestos, publicações e exposições do início do século - se apresenta aqui como aquela que usufruía de novas oportunidades de crescimento educacional e profissional, além da liberdade de atuar no campo dos esportes, da vida social e no mercado de trabalho.

75. Marins (1998, p. 191)
A ideia de racionalização do trabalho a partir de seus espaços e equipamentos se relacionava à possibilidade de libertar, ou pelo menos aliviar, o fardo das atividades domésticas no cotidiano familiar. Assim, novos desenhos para a cozinha foram propostos e até mesmo suprimidos em diversos empreendimentos, sugerindo novas práticas que permitiriam às mulheres modernas ${ }^{74}$ ficarem menos sobrecarregadas com essas atividades.

No entanto, ao se analisar as plantas dos grandes imóveis brasileiros, percebe-se que o duplex possuiu um apelo menos ligado à funcionalidade ou à dinamização do ambiente doméstico, mas principalmente à questão da distinção. A presença de dormitórios de empregada, de acessos sociais e de serviço separados, contradizem os princípios de emancipação individual das experiências europeias do entreguerras, mas também demandam um incremento de área que afeta até mesmo a leitura tipológica desses imóveis: em vez da compacidade das proporções que exigiriam uma coordenação funcional entre pavimentos, sobressaise uma associação com sobrados empilhados. Os modos de morar permaneciam tradicionais, como uma demonstração de que as famílias que optavam pela vida nos condomínios poderiam ser respeitadas. "Era imperioso conferir exclusividade e luxo àqueles que se dispusessem a migrar dos palacetes para os apartamentos, já que eram um gênero de moradia coletiva, aspecto nauseante para as elites, que condenavam os cortiços, estalagens e casas de cômodo". ${ }^{75}$ As amplas áreas sociais e de serviço coexistentes atestam que, mesmo com a modernidade exposta nas técnicas construtivas e no despojamento ornamental, qualquer grupo familiar poderia habitar os conjuntos.

A complicada relação entre modernidade e tradição nos conjuntos modernos aqui analisados se reforça na análise atenta das fotos de René Burri e Lucien Hervé para a Unidade de Habitação de Marselha presentes no acervo do Museu de Arte Moderna de Nova lorque (MoMA). Homens, mulheres e crianças estão representadas realizando atividades que remetem ao tradicional: mulheres cuidando de crianças ou costurando; crianças brincando no terraço-jardim, homens a fumar, beber ou ler em suas mesas. Enquanto o discurso do arquiteto se volta para a máquina de morar que possibilitaria uma dinâmica doméstica diferente e inovadora, as imagens mostram outra realidade. As fotos - repetidamente reproduzidas e divulgadas em diversas publicações que tratam da obra de Le Corbusier - demonstram que o apartamento é inspirado na família moderna, e que poderia também ser desfrutada por aquelas tradicionais.

Ainda sobre a proposta de habitação na arquitetura moderna, este artigo se propõe ainda a apontar como a ideia do morar em nível esteve associada à economia construtiva e como este discurso se perde nas experiências realizadas 
ao longo das décadas. Se a discussão da habitação mínima e a proposta do "Tipo F" realizadas nas primeiras décadas do século XX tinham como fim economizar na construção de conjuntos habitacionais pela restrição às áreas de circulação e substituição das de serviço de cada família por equipamentos coletivos, ao longo das décadas, os empreendimentos habitacionais que se utilizaram da tipologia perderam esta consideração econômica. Pelos desenhos analisados, é possível perceber que as áreas se ampliaram e os corredores passaram a se repetir nos andares, segregando parrões e empregados que, muitas vezes, habitam no mesmo endereço.

Por fim, é perceptível que o argumento da transformação dos hábitos e da economia construtiva se perdeu em um modelo de habitação que se afirmava pela distinção de seus moradores por meio da apreciação de certos desenhos, determinados arquitetos e privilegiadas localizações geográficas. Os anúncios dos jornais revelam os atributos de atração dos investidores, a exemplo do que ocorre no edifício Eiffel, cuja peça de divulgação ressalta

Apartamentos todos de frente para a Praça da República - tipo duplex - com absoluta separação entre as partes nobres, de repouso e de serviço. [...] Arquitetura: para tão aristocrática localização, um grande arquiteto: Oscar Niemeyer. Projetando o edifício Eiffel, o renomado arquiteto patrício atinge também o clímax da sua arte, uma arte que aqui se traduz numa feliz combinação de funcional distribuição das peças, máximo conforto e excepcional beleza arquitetônica. ${ }^{76}$

Assim, o discurso da economia e da funcionalidade apresentado em diversos cálculos, diagramas, projetos e textos das primeiras décadas do século XX se perdeu à medida que a tipologia ampliava seu programa em função de áreas maiores destinadas ao convívio social e aos serviços, em uma tentativa de atrair investidores interessados em edifícios com uma estética da arquitetura moderna, porém com uma disposição espacial tradicional. 


\section{REFERÊNCIAS}

FONTES IMPRESSAS

FOLHA DA MANHÃ. No ângulo máximo da Praça da República. Folha de São Paulo, São Paulo, ano 32, n. 29.178, 23 mar. 1952, p. 4.

LIVROS, ARTIGOS E TESES

ANELLI, Renato. Rino Levi: arquitetura e cidade. São Paulo: Romano Guerra, 2001.

ANGUIANO, Guillermo Plazola. 50 años de arquitectura mexicana, 1948-1998. Ciudad del México, DF: Plazola, 1999.

ARGAN, Giulio Carlo. Arte moderna: do iluminismo aos movimentos contemporâneos. São Paulo: Companhia das Letras, 1992.

ATIQUE, Fernando. Memória moderna: a trajetória do Edifício Esther. 2. ed. São Carlos: RiMa, 2013.

BARBARA, Fernanda. Duas tipologias habitacionais: o conjunto Ana Rosa e o Edifício Copan: contexto e análise de dois projetos realizados em São Paulo na década de 1950. 2004. $332 \mathrm{f}$. Dissertação (Mestrado em Estruturas Ambientais e Urbanas) - Faculdade de Arquitetura e Urbanismo, Universidade de São Paulo, São Paulo, 2004.

BLIZNAKOV, Milka. Soviet housing during the experimental years, 1918 to 1933. In: BRUMFIELD, William Craft; RUBLE, Blair Ruble (Ed.). Russian bousing in the Modern Age: design and social history. Cambridge, UK: Cambridge University Press, 1993. p. 85-147.

BOESIGER, Willy. Le Corbusier: 1910-65. Barcelona: Gustavo Gili, 1971.

BONDUKI, Nabil; SILVA, Elaine Pereira; KOURY, Ana Paula. Conjunto residencial Japurá: uma unidade de habitação no centro da cidade. In: BONDUKI, Nabil; KOURY, Ana Paula (Org.). Os pioneiros da habitação social no Brasil. São Paulo: Editora Unesp, 2014. v. 3, p. 136-157. 
BOTAS, Nilce Aravecchia. Estado, arquitetura e desenvolvimento: a ação habitacional do Iapi. São Paulo: Editora Unifesp, 2016.

BOURDIEU, Pierre. A distinção: crítica social do julgamento. São Paulo: Edusp, 2007.

BRUNA, Paulo Júlio Valentino. Os primeiros arquitetos modernos: habitação social no Brasil. São Paulo: Edusp, 2015.

COELHO, Carla Maria Teixeira. Conjunto Residencial Parque Guinlee a preservação de edifícios residenciais modernos. 2006. 204 f. Dissertação (Mestrado em Arquitetura) - Faculdade de Arquitetura e Urbanismo, Universidade Federal do Rio de Janeiro, Rio de Janeiro, 2006.

COHEN, Jean Louis. Le Corbusier, 1887-1965: lirismo da arquitectura da Era da Máquina. Lisboa: Taschen, 2005.

O futuro da arquitetura desde 1889: uma história mundial. São Paulo: Cosac \& Naify, 2013.

COSTA, Lúcio. Parque Guinle. Anos 40. In: COSTA, Lúcio. Registros de uma vivência. 2. ed. São Paulo: Empresa das Artes, 1995. p. 205-213.

COSTA, Sabrina Studart Fontenele. Edifícios modernos e traçado urbano no centro de São Paulo. São Paulo: Annablume, 2015.

CURTIS, William. Arquitetura moderna desde 1900. Porto Alegre: Editora Bookman, 2008.

ELEB, Monique. Lugares, gestos e palavras do conforto em casa. V!rus, São Carlos, n. 5, jun. 2011. Não paginado. Disponível em: <https://bit.ly/2CZduYC>. Acesso em: 6 fev. 2018.

FRAMPTON, Keneth. História crítica da arquitetura moderna. São Paulo: Martins Fontes, 2000.

GARAY, Graciela (Coord.). Rumores y retratos de un lugar de la modernidad: historia oral del multifamiliar Miguel Alemán, 1949-1999. Ciudad del México, DF: Instituto Mora, 2002.

GOLDMAN, Wendy. Mulher, Estado e revolução: política familiar e vida social soviéticas, 19171936. São Paulo: Boitempo, 2014.

GOODWIN, Philip. Brazil builds: architecture new and old, 1652-1942. New York: MoMA, 1943. 
GORELIK, Adián. Das vanguardas a Brasília: cultura urbana e arquitetura na América Latina. Belo Horizonte: Editora UFMG, 2005.

KHAN-MAHOMEDOV, Selim Omarovitch. Ya: Ginsburg 1892-1946. In: SHVIDKOVSKIÎ, Oleg Aleksandrovich (Ed.). Building in the USSR (1917-1932). New York: Praeger, 1971. p. 90-96.

KNEESE DE MELLO, Eduardo. Apartamentos para industriários: Iapi delegacia de São Paulo, Rua Japurá, São Paulo. Acrópole, São Paulo, n. 119, p. 281-287, 1948.

Projeto de um prédio de apartamentos a, rua Japurá. São Paulo: Iapi, [19--?].

KOPP, Anatole. Arquitectura y urbanismo soviéticos de los años veinte. Barcelona: Lumen, 1974.

LEAL, Daniela Viana. Oscar Niemeyer e o mercado imobiliário de São Paulo na década de 1950: o escritório satélite sob a direção do arquiteto Carlos Lemos e os edifícios encomendados pelo Banco Nacional Imobiliário. 2003. 282 f. Dissertação (Mestrado em História da Arte) Instituto de Filosofia e Ciências Humanas, Universidade de Campinas, Campinas, 2003.

LEFÈVRE, José Eduardo de Assis. De beco a avenida: a história da Rua São Luiz. São Paulo: Edusp, 2006.

LEMOS, Carlos Alberto Cerqueira. Cozinhas etc. São Paulo: Perspectiva, 1976.

LIRA, José Correia Tavares. Warchavchik: fraturas da vanguarda. São Paulo: Cosac Naify, 2011.

MARINS, Paulo César Garcez. Habitação e vizinhança: limites de privacidade no surgimento das metrópoles brasileiras. In: SEVCENCO, Nicolau (Org.). Da belle époque à era do rádio: história da vida privada no Brasil. São Paulo: Companhia das Letras, 1998. v. 3, p. 131-214.

MUMFORD, Eric Paul. The CIAM discourse on urbanism, 1928-1960. Cambridge, MA: MIT Press, 2000.

NASCIMENTO, Flavia Brito. Blocos de memórias: habitação social, arquitetura moderna e patrimônio cultural. São Paulo: Edusp, 2017.

NASCIMENTO, Flavia Brito; BOTAS, Nilce Aravecchia. Penha: de um projeto autoral a uma proposta funcional da equipe do Iapi. In: BONDUKI, Nabil; KOURY, Ana Paula (Org.). Os pioneiros da habitação social no Brasil. São Paulo: Editora Unesp, 2014. v. 3, p. 196-217. 
NAVAILH, Françoise. O modelo soviético. In: PERROT, Michelle; DUBY, Georges. História das mulheres no ocidente. Porto: Afrontamento, 1995. p. 279-307.

REGINO, Aline Nassaralla; PERRONE, Rafael Antonio Cunha. Eduardo Augusto Kneese de Mello: sua contribuição para habitação coletiva em São Paulo. Risco, São Carlos, v. 1, n. 9, p. 56-97, 2009.

ROBERTO, Marcelo; ROBERTO, Milton. Um edifício tipo "duplex" no Rio. Arquitetura e Construção, Rio de Janeiro, n. 638, p. 42-44, 1939.

ROSSETTO, Rossella. Produção imobiliária e tipologias residenciais modernas em São Paulo, 1945-1964. 2002. 210 f. Tese (Doutorado em Estruturas Ambientais e Urbanas) - Faculdade de Arquitetura e Urbanismo, Universidade de São Paulo, São Paulo, 2002.

RUBINO, Silvana. Lugar de mulher: arquitetura e design moderno, gênero e domesticidade. 2017. 220 f. Tese (Livre Docência em História da Arquitetura e do Urbanismo) - Instituto de Filosofia e Ciências Humanas, Universidade de Campinas, Campinas, 2017.

SAMPAIO, Maria Ruth (Org.). Habitação e cidade. São Paulo: Fapesp, 1998.

SEGAWA, Hugo. Arquiteturas no Brasil: 1900-1990. São Paulo: Edusp, 1999.

SEVCENKO, Nicolau. Orfeu extáltico na metrópole: São Paulo, sociedade e cultura nos frementes anos 20. São Paulo: Companhia das Letras, 2003.

SILVA, Joana Mello de Carvalho. Habitar a metrópole: os apartamentos quitinetes de Adolf Franz Heep. Anais do Museu Paulista, São Paulo, v. 21. n. 1. p. 141-157, 2013.

SOUZA, Luiz Felipe Machado Coelho. Irmãos Roberto, arquitetos. Rio de Janeiro: Rio Books, 2014.

TAFURI, Manfredo. Esfera y el laberinto: vanguardias y arquitectura de piranesi a los anos setenta. Barcelona: Gustavo Gili, 1984.

VILLA, Simone Barbosa. Apartamento metropolitano: habitações e modos de vida na cidade de São Paulo. 2002. 220 f. Dissertação (Mestrado em Arquitetura e Urbanismo) - Escola de Engenharia de São Carlos, Universidade de São Paulo, São Carlos, 2002.

ZABAlBEASCOA, Anatxu. Tudo sobre a casa. São Paulo: Gustavo Gili, 2013. 


\section{ENTREVISTAS}

Entrevista com o professor Carlos Lemos realizada na FAU-Maranhão no dia 19 de janeiro de 2016.

Artigo apresentado em 07/03/2018. Aprovado em 22/08/2018

\section{(cc) BY}

All the contents of this journal, except where otherwise noted, is licensed under a Creative Commons Attribution License 